\title{
Revised Telychian-Sheinwoodian (Silurian) stratigraphy of the Laurentian mid-continent: building uniform nomenclature along the Cincinnati Arch
}

\author{
Carlton E. Brett, Bradley D. Cramer, Patrick I. Mclaughlin, Mark A. Kleffiner, \\ WILLIAM J. SHOWERS \& JAMES R. THOMKA
}

\begin{abstract}
Recent detailed studies of the physical, bio-, and chemostratigraphy of upper Llandovery to middle Wenlock strata of the Cincinnati Arch area, primarily SW Ohio and SE Indiana and to a lesser extent west-central Kentucky, indicate a regionally extensive pattern of units, correlatable in detail over more than $30,000 \mathrm{sq} . \mathrm{km}$. This relatively simple stratigraphy has been obscured by the development of local names and by different usage of the same name in different areas. Herein we review and update this stratigraphical succession to provide uniform nomenclature and correlation of these units throughout the study area. The units as redefined and/or extended in this study include the Lee Creek, Dayton, Osgood, Lewisburg, Massie, and Laurel formations. Extension of the unit name Salamonie Dolomite is herein discouraged south of the Salamonie type area in NE Indiana. The term Dayton Dolostone is herein redefined; it is overlain by the Osgood Formation, which is also redefined here as equivalent to Foerste's (1897) 'Lower Osgood Clay'. The Lewisburg Limestone/Dolostone is reintroduced here as a formal name at the rank of formation to include a thin interval of pelmatozoan-brachiopod dolomitic pack- to grainstone formerly termed 'Middle Osgood Limestone' in Indiana and 'Laurel of Ohio' (in part) in SW Ohio. The term Massie Shale, defined in SW Ohio, is extended at formation rank throughout the study area as equivalent to the 'Upper Osgood Clay' and unnamed shale unit of the lower part of the Laurel (subunit 2) in Kentucky. Key words: Indiana, Ohio, Kentucky, Silurian, chronostratigraphy, correlation.
\end{abstract}

Brett, C.E., Cramer, B.D., Mclaughlin, P.I., Kleffner, M.A., Showers, W.J. \& ThOmKA, J.R. 2012. Revised Telychian-Sheinwoodian (Silurian) stratigraphy of the Laurentian mid-continent: building uniform nomenclature along the Cincinnati Arch. Bulletin of Geosciences 87(4), 733-753 (11 figures). Czech Geological Survey, Prague. ISSN 1214-1119. Manuscript received August 22, 2011; accepted in revised form May 31, 2012; published online October 2, 2012; issued October 17, 2012.

Carlton E. Brett (corresponding author) \& James R. Thomka, Department of Geology, University of Cincinnati, 2624 Clifton Avenue, Cincinnati, Ohio 45221, USA; brettce@ucmail.uc.edu・Bradley D. Cramer, Kansas Geological Survey/Department of Geology, University of Kansas, 1930 Constant Avenue, Lawrence, Kansas 66049, USA; current address: Department of Geoscience, University of Iowa, Iowa City, Iowa 52242, USA; cramerbd@gmail.com • Patrick I. McLaughlin, Wisconsin Geological and Natural History Survey, 3817 Mineral Point Road, Madison, Wisconsin 53705, USA; pimclaughlin@wisc.edu・Mark A. Kleffner, Division of Earth History, School of Earth Sciences, The Ohio State University at Lima, 4240 Campus Drive, Lima, Ohio 45804, USA; mkleffner@lima.ohio-state.edu・William J. Showers, Department of Marine, Earth, and Atmospheric Sciences, North Carolina State University, Campus Box 8208, Raleigh, North Carolina 27695,USA; wjshower@ncsu.edu

The Silurian strata of the Cincinnati Arch region have been studied for more than a century (e.g. Orton 1870, 1871; Foerste 1896, 1897); however, a number of problems remain (Fig. 1). Biostratigraphically, these rocks have been rather poorly dated, in large measure because of the virtual absence of zonal graptolites and the difficulty in obtaining diagnostic conodonts at most levels (owing to pervasive dolomitization), thus limiting precise global chronostratigraphical correlation of these strata. Recent studies from North America have begun to integrate improved conodont-based biostratigraphy with high-resolution sequence stratigraphy, event stratigraphy, and carbon isotope chemostratigraphy in an effort to improve global chronostratigraphical correlation of these extensive Laurentian Silurian outcrops (see Brett \& Ray 2005; Cramer \& Saltzman 2005; Cramer et al. 2006, 2010a, 2010b, 2011; McLaughlin et al. 2008; Kleffner et al. 2012a). As a result of this renewed synergistic research, we have documented, as Foerste suspected, that exceptionally widespread and coeval stratigraphical patterns exist throughout a vast 


\begin{tabular}{|c|c|c|c|c|c|c|c|c|c|}
\hline \multicolumn{3}{|c|}{$\begin{array}{cc} & \text { Foerste } \\
\text { Global } & (1897) \\
\text { Series Stage } & (E+S E \text { Indiana })\end{array}$} & $\begin{array}{l}\text { Shaver et al. } \\
\quad(1986) \\
(E+S E \text { Indiana) }\end{array}$ & \multirow{3}{*}{$\begin{array}{l}\text { Peterson (1986) } \\
\text { (W. Central Kentucky) } \\
\text { (Western outcrop belt) } \\
\begin{array}{c}\text { subunit } \\
3\end{array}\end{array}$} & $\begin{array}{l}\text { Foerste } \\
\text { (1917) } \\
\text { (W Ohio) }\end{array}$ & $\begin{array}{l}\text { Foerste } \\
\text { (1935) } \\
\text { (W Ohio) }\end{array}$ & $\begin{array}{l}\text { Foerste } \\
(1929) \\
\text { (SW Ohio) }\end{array}$ & $\begin{array}{l}\text { Foerste } \\
\text { (1935) } \\
\text { (SW Ohio) }\end{array}$ & $\begin{array}{l}\text { Slucher (2004) } \\
\text { Schumacher } \\
\text { et al. (2012) } \\
\text { (SW Ohio) }\end{array}$ \\
\hline \multirow{5}{*}{$\begin{array}{l}\frac{\pi}{3} \\
\frac{\pi}{2} \\
\frac{\pi}{2}\end{array}$} & \multirow{5}{*}{ 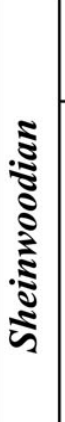 } & \multirow{2}{*}{$\begin{array}{l}\text { Laurel } \\
\text { Fm. }\end{array}$} & \multirow{2}{*}{ Laurel Mbr. } & & $\begin{array}{l}\text { Durbin Fm. } \\
\text { Euphemia Mbr. }\end{array}$ & Euphemia Fm. & Euphemia & Euphemia & Euphemia \\
\hline & & & & & Laurel Fm. & Laurel Fm. & & Fm. & Fm. \\
\hline & & U. Shale & \multirow[b]{2}{*}{$\begin{array}{l}\text { Salamonie } \\
\text { Fm. }\end{array}$} & \begin{tabular}{|cc|} 
Laurel & \\
\cline { 2 - 2 } Fm. & sub- \\
unit \\
\end{tabular} & \multirow[b]{3}{*}{$\begin{array}{l}\text { Osgood } \\
\text { Fm. }\end{array}$} & Osgood Fm. & Massie Fm. & Massie Fm. & Massie Fm. \\
\hline & & M. Limestone & & subunit 1 & & \multirow{3}{*}{$\begin{array}{l}\text { Dayton } \\
\text { Fm. }\end{array}$} & Laurel Fm. & 'Laurel' Fm. & Laurel Fm. \\
\hline & & $\begin{array}{l}\text { Osgood } \\
\text { Fm. } \\
\text { L. Shale }\end{array}$ & Osgood Mbr. & Osgood & & & $\begin{array}{l}\text { Osgood } \\
\text { Fm. }\end{array}$ & $\begin{array}{l}\text { 'Osgood' } \\
\text { Fm. }\end{array}$ & $\begin{array}{l}\text { Osgood } \\
\text { Fm. }\end{array}$ \\
\hline \multirow{2}{*}{$\frac{\sqrt{3}}{\sqrt[3]{3}}$} & 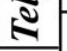 & \multirow{2}{*}{$\begin{array}{c}\text { Brass- } \\
\text { field Fm. }\end{array}$} & Lee Creek Mbr. & \multirow{2}{*}{$\begin{array}{l}\text { Brass- } \\
\text { field Fm. }\end{array}$} & & & Dayton Fm. & Dayton Fm. & Dayton Fm. \\
\hline & Ae. & & & & Brassfield Fm. & Brassfield Fm. & Brassfield Fm. & Brassfield Fm. & Brassfield Fm. \\
\hline
\end{tabular}

Figure 1. Brassfield-Laurel lithostratigraphical terminology from the Indiana, Kentucky and Ohio Tristate area. Foerste (1897) introduced the Osgood and revised the Laurel. Shaver et al. (1986) represents the current use of these terms by the Indiana Geological Survey. Peterson (1986) represents the currently accepted stratigraphy of west-central Kentucky. The use of a separate western Ohio terminology (as per Foerste 1935) was not recognized during the recent remapping of the state (Slucher et al. 2006) and the southwestern Ohio terms are the currently recognized unit names for the Ohio portion of the study area. The chronostratigraphical columns shown at left refer to the position of international series and stage boundaries as identified in Shaver $e$ al. (1986), not necessarily as Foerste understood them at the dawn of the $20^{\text {th }}$ century. Similarly, the geographical areas are broken apart by vertical lines to highlight the fact that a diagram such as this that shows no stratigraphical gaps can easily be over-interpreted. For example, we do not intend to show that the lower part of the Osgood in western Ohio was considered equivalent to the Lee Creek Member of the Brassfield Formation in Indiana. In fact, most of the Telychian Stage is missing throughout the study area, and only small slices are preserved.

region spanning at least the southwestern Ohio-southeastern Indiana-west-central Kentucky Tristate area, if not farther. Historically, however, this pattern has been obscured by inconsistent lithostratigraphical terminology and correlation. Units of remarkably similar facies that are demonstrably coeval have been referred to by a variety of names, have changed ranks and/or names at state and county boundaries ("state-line-faults") and have been variably assigned as subdivisions of larger units. The result is an inconsistent, redundant, and confusing terminology that conveys the impression of substantial change where none, in fact, exists and masks the through-going character of many rock units.

In the present paper we revise the lithostratigraphical terminology of units belonging to the middle to upper parts of the Telychian Stage and lower to middle parts of the Sheinwoodian Stage in the states of Ohio, Indiana, and Kentucky. We review the standing nomenclature, standardize a number of redundant, miscorrelated, overly inclusive, or misleading names, and redefine a number of existing lithostratigraphical units. Our guiding principles in doing so include the following points: a) priority should be given to a simple and consistent nomenclature that can be applied over as wide an area as is possible and justified; b) wherever possible, established names should be retained but redefined with unambiguous boundaries; c) coeval lithological units should be given the same name despite minor gradational facies changes; and d) formations should not contain significant discontinuities or sequence bounding unconformities. We herein examine and revise the lithostratigraphical nomenclature of Silurian strata along the western side of the Cincinnati Arch (Fig. 1) in southwestern Ohio and southeastern Indiana, and to a lesser extent, west-central Kentucky.

\section{Laurentian mid-continent stratigraphy}

The majority of North America was inundated by a tropical epeiric sea during the Silurian (Fig. 2), and the bathymetry of the mid-continent portion was dominated by three major basins (the Appalachian, Illinois, and Michigan basins) that were separated by a series of structural arches. One of these arches, commonly referred to as the "Cincinnati Arch", separated the distal Appalachian Basin from the Illinois Basin as a paleobathymetric high located across southwestern Ohio, southeastern Indiana, and northern Kentucky. Below, we discuss a series of outcrops from western Ohio to southeastern Indiana to west-central Kentucky, largely along the crest and proximal flanks of the structural high (Indiana-Ohio Platform of Slucher et al. 2006, sometimes referred to as the "Cincinnati Arch" or "proto-Cincinnati Arch"), that illustrate the remarkable stratigraphical consistency of Telychian-Sheinwoodian units across the study area. 

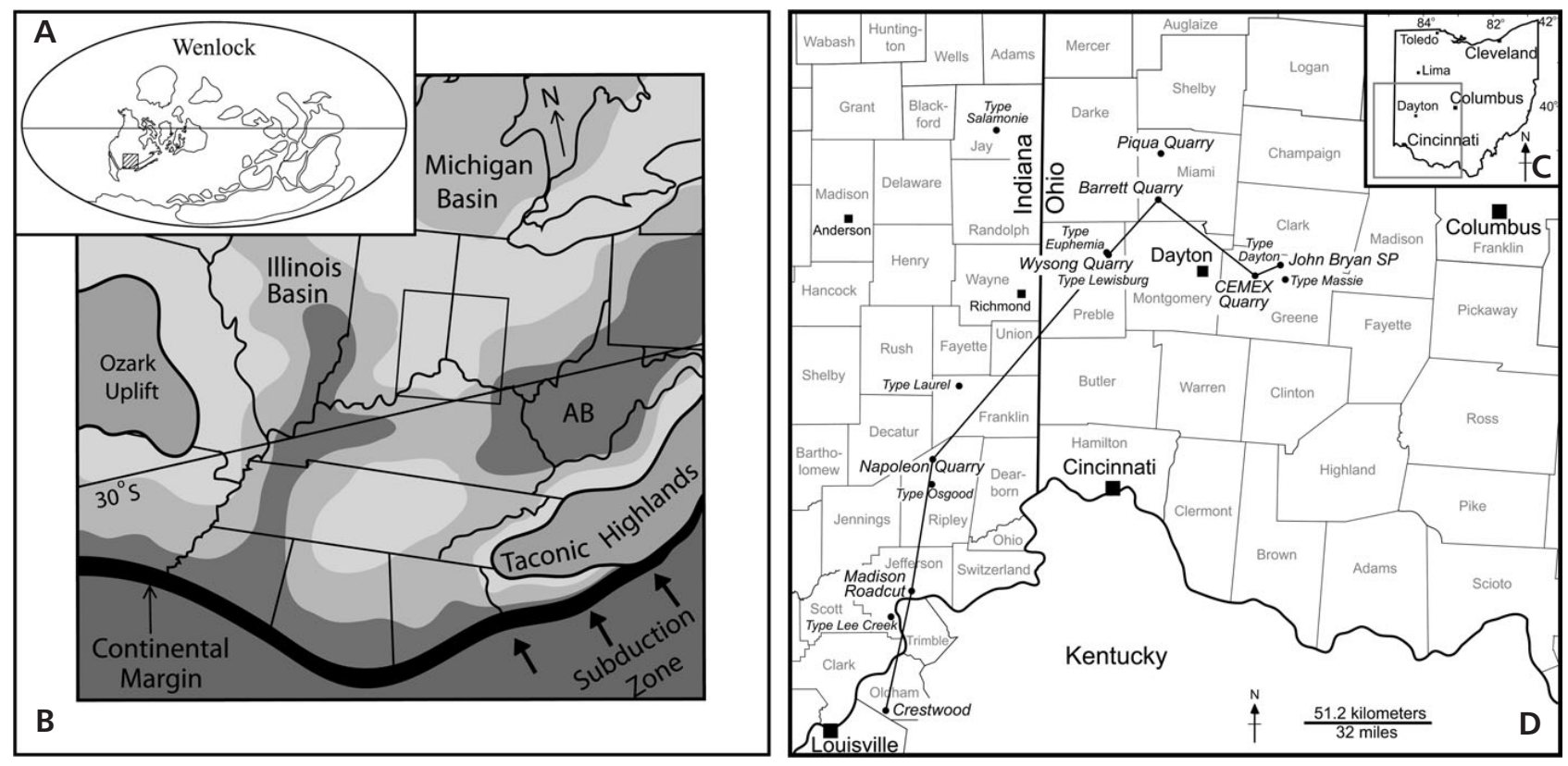

Figure 2. Wenlock palaeogeography (Panel A) and Laurentian mid-continent relative palaeobathymetry (Panel B) modified from Cramer \& Saltzman (2005) shown together with Ohio state map (Panel C) and Tri-State county map (Panel D). Locality map (Panel D) shows important Telychian-Sheinwoodian localities and type sections of lithostratigraphical units discussed herein.

The stratigraphic columns produced for the McLaughlin et al. (2008) field guide are utilized here. The detailed lithostratigraphical information provided by these measured sections serves as the foundation for the current project. The reader should consult McLaughlin et al. (2008) for driving directions to the sections included here as well as for a detailed legend to accompany the stratigraphical columns. A complete locality map for all sections discussed in this report is provided in Fig. 2.

At the close of the $19^{\text {th }}$ century, the lower to middle Silurian strata of the Indiana-Kentucky-Ohio Tristate area were divided into three units; the Brassfield ("Clinton"), Osgood, and Laurel formations (e.g. Foerste 1897, 1906). More than a century later, however, nomenclatural mismatches across state borders and the introduction of new local terminology have obscured the remarkably consistent stratigraphical succession in the Tristate area (Fig. 1). With the addition of new cores and roadcuts unavailable to Foerste, as well as new chronostratigraphical tools such as improved conodont biostratigraphy and carbon isotope $\delta^{13} \mathrm{C}_{\text {carb }}$ chemostratigraphy, many of these correlations can now be updated and/or revised to improve significantly our ability to correlate these strata across state boundaries. The confusion regarding the Silurian units in question can be divided into three major issues that are important to address in overview before discussing individual stratigraphical sections. The "Osgood-Laurel problem", the "Dayton problem", and the "MassieWaldron problem" are the backdrop for this inter-state stratigraphical study and are discussed briefly below.

\section{The Osgood-Laurel problem}

The Osgood and Laurel formations represent the bulk of the strata included in the present investigation and their precise correlation is critical to resolving many of the so-called "state-line-faults". The presently accepted stratigraphy of the Osgood-Laurel interval throughout the Tristate area suffers from an inconsistent application of the unit names Osgood and Laurel (Fig. 3). Here, we propose standardization of the nomenclature for the Osgood-Laurel interval that will allow common use of terminology in all three states.

Comparing Indiana and Kentucky nomenclature is straightforward given that only the two terms, Osgood and Laurel, have been used. Foerste (1935) suggested that the typical tri-partite Osgood of Indiana - a Lower Osgood Clay/Shale, a Middle Osgood Limestone/Dolostone, and an Upper Osgood Clay/Shale - could be traced readily across the border and throughout the Kentucky portion of the study area. In the remapping of Kentucky (see overview in Peterson 1986) the USGS chose to place the base of the Laurel Formation in Kentucky at a position referred to as the base of the Middle Osgood Limestone across the border in Indiana. The middle and upper components of the original tri-partite Osgood were still recognized by Peterson (1986) as consistent stratigraphical packages within his Laurel Formation as "subunits 1 and 2", but they were not placed within the Osgood Formation as Indiana usage would favour.

The comparison between Indiana nomenclature and that used in Ohio is fraught with many complications, not 
Indiana Kentucky Ohio This Report (Shaver et al. 1986) $\quad$ (Peterson 1986) $\quad$ (Slucher et al. 2006) (Tristate Area)

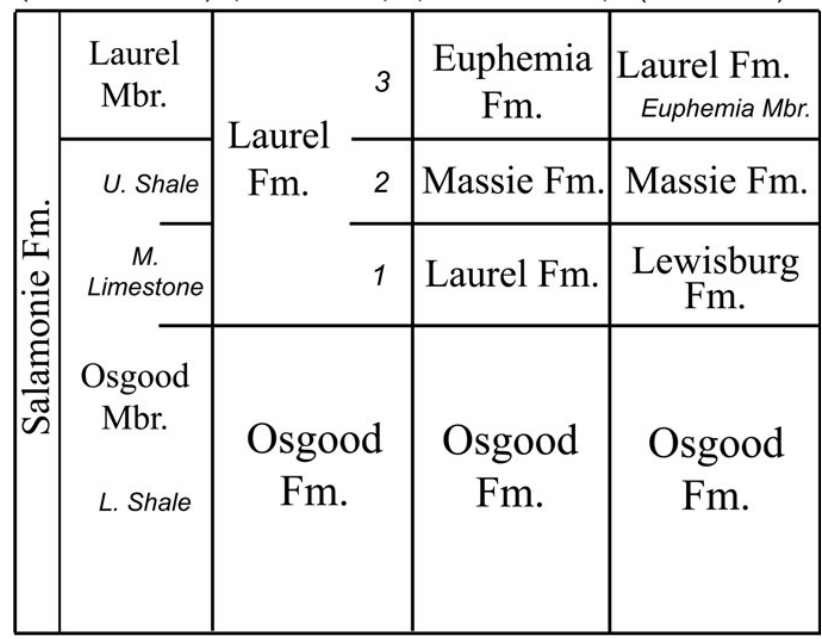

Figure 3. Currently accepted Osgood-Laurel stratigraphical nomenclature of the Indiana-Kentucky-Ohio Tristate area together with the proposed revisions presented herein shown at right. The Ohio column shown represents the classical southwestern Ohio stratigraphy as recently re-mapped by Slucher et al. (2006).

\begin{tabular}{|c|c|c|c|c|c|}
\hline \multicolumn{2}{|c|}{$\begin{array}{c}\text { Indiana } \\
\text { (Shaver etal. 1986) }\end{array}$} & $\begin{array}{l}\text { Foerste } \\
\text { (1935) } \\
\text { (w Ohio) }\end{array}$ & $\begin{array}{c}\text { This Report } \\
\text { (W Ohio) }\end{array}$ & $\begin{array}{l}\text { Foerste } \\
(1935)^{*} \\
\text { (SW Ohio) }\end{array}$ & $\begin{array}{l}\text { This Report } \\
\text { (SW Ohio) }\end{array}$ \\
\hline \multirow{5}{*}{ 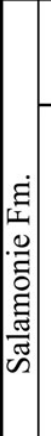 } & Laurel & $\begin{array}{l}\text { Euphemia } \\
\text { Fm. }\end{array}$ & \multirow{2}{*}{$\begin{array}{l}\text { Laurel Fm. } \\
\text { Euphemia Mbr. }\end{array}$} & \multirow{2}{*}{$\begin{array}{l}\text { Euphemia } \\
\text { Fm. }\end{array}$} & \multirow{2}{*}{$\begin{array}{l}\text { Laurel Fm. } \\
\text { Euphemia Mbr. }\end{array}$} \\
\hline & & Laurel Fm. & & & \\
\hline & U. Shale & $\begin{array}{l}\text { Osgood } \\
\text { Fm. }\end{array}$ & Massie Fm. & Massie Fm. & Massie Fm. \\
\hline & $\begin{array}{c}M . \\
\text { Limestone }\end{array}$ & \multirow[b]{2}{*}{$\begin{array}{l}\text { Dayton } \\
\text { Fm. }\end{array}$} & $\begin{array}{c}\text { Lewisburg } \\
\text { Fm. }\end{array}$ & Laurel Fm. & $\begin{array}{c}\text { Lewisburg } \\
\text { Fm. }\end{array}$ \\
\hline & $\begin{array}{l}\text { Osgood } \\
\text { Mbr. } \\
\text { L. Shale }\end{array}$ & & $\begin{array}{l}\text { Osgood } \\
\text { Fm. }\end{array}$ & $\begin{array}{l}\text { Osgood } \\
\text { Fm. }\end{array}$ & $\begin{array}{l}\text { Osgood } \\
\text { Fm. }\end{array}$ \\
\hline & & & & Dayton Fm. & Dayton Fm. \\
\hline
\end{tabular}

Figure 4. Historical and revised Dayton-Osgood-Laurel nomenclature from western and southwestern Ohio. *Note: The southwestern nomenclature shown in Foerste (1935) is identical to the currently accepted nomenclature on the Ohio state map (Slucher et al. 2006). The proposed revisions allow consistent application of terminology across the western to southwestern Ohio transition.

the least of which is the introduction of new lithostratigraphical terminology not used in Indiana, namely the Dayton, Massie, Euphemia, Springfield, and Cedarville formations. The stratigraphical use of the terms Osgood and Laurel in western Ohio (Preble, NW Montgomery, Miami and Darke counties) and southwestern Ohio (E Montgomery, Greene, and SW Clarke counties) di- verged during the past century (Figs 1, 4), and the exposures in Greene County, Ohio, now play a pivotal role in the presently accepted Ohio nomenclature due to 1) the presence of the original type section of the Massie Formation, and 2) the identification of a thin carbonate unit between the Massie and Osgood formations termed the "Laurel" Formation (Slucher 2004, Slucher et al. 2006, Schumacher et al. 2012). The Dayton and Massie formations are discussed below, but it is important at this point to highlight the fact that recent data can now demonstrate that the stratigraphy preserved in Greene County, Ohio, including the classical sections in and around Yellow Springs and John Bryan State Park, can be correlated directly with the Osgood-Laurel nomenclature in use throughout the Tristate area (Fig. 3, see text below).

\section{The Dayton problem}

The name "Dayton Limestone" was used locally by drillers and quarrymen long before the term was formalized by Orton (1870), and it is partly through this informal origin that the name has been applied to a wide array of stratigraphical units throughout the Ohio, West Virginia, and Kentucky portion of the Appalachian Basin (e.g. Horvath 1969, Ryder 2006, McLaughlin et al. 2008, Kleffner et al. 2012a). The term Dayton has been applied to at least three distinct lithostratigraphical units within Ohio (Fig. 4), one in western Ohio (Preble, NW Montgomery, Miami and Darke counties), another in southwestern Ohio (E Montgomery, Greene and SW Clarke counties), and a third in southern Ohio (Clinton, Highland, Adams, and Brown counties and locations farther east and southeast). Only the first two areas, western and southwestern Ohio, are included in the present study area, but a brief note about the use of the term Dayton in southern Ohio is included below.

In western Ohio, where Foerste's original (1897) "Lower Osgood Clay" becomes more calcareous, the Middle Osgood Limestone and Lower Osgood Clay were grouped together as the Dayton Formation (e.g. Foerste 1935, p. 162). The currently recognized stratigraphy for the more calcareous successions in western Ohio avoided the use of this sense of Dayton by mapping these strata as "Clinton/Cataract Undifferentiated" (Slucher et al. 2006). In effect, this is an Ohio solution to the same problem addressed with the introduction of the term Salamonie in Indiana (Pinsak \& Shaver 1964). We suggest here that strata south of a line running approximately from western Miami and central Darke counties in Ohio to Fayette and Decatur counties in Indiana can be readily identified using the revised stratigraphical units proposed herein without the need to resort to the less precise names of Salamonie or Clinton/Cataract Undifferentiated, and extension of these terms into southern Indiana and western and southwestern Ohio is discouraged. 
Foerste (1935, p. 162) clearly realized that this western Ohio usage of Dayton was synonymous with his original Lower and Middle Osgood, but what he did not realize was that in Greene County (SW Ohio), the unit referred to as Dayton sits below true Lower Osgood Clay (in a Foerste 1897 Indiana sense) and therefore is a stratigraphical unit below what he referred to as Dayton in western Ohio (Fig. 4). The term eventually crosses out of the present study area and into the southern Ohio nomenclature as well (Estill, Bisher, Lilly, Peebles, etc.) as yet a third distinct unit that sits above the Brassfield Formation and now rests below the Estill Formation. We suggest here that the term Dayton not be extended into this southern Ohio terminology, and suggest that the existing term Waco is preferred for the carbonate unit below the Estill Formation in southern Ohio. Here, we restrict the term Dayton Dolostone to the sense in which it has been used in southwestern Ohio, that is, eastern Montgomery and Greene counties including the area around Dayton, Yellow Springs, and John Bryan State Park (Schumacher et al. 2012, Kleffner et al. 2012a; see below), as a unit that lies above the Brassfield Formation and below the Osgood Formation.

\section{The Massie-Waldron problem}

Foerste's early attempts to trace his Osgood and Laurel formations from southeastern Indiana into western Ohio were largely successful, but the transition into southwestern Ohio was more problematical. Foerste (1917, p. 189) stated, "Since there is little change in the thickness of the Laurel limestone and of the Osgood clay in proceeding from Lewisburg eastward to Ludlow Falls and Covington [i.e. within western Ohio], it is probable that these members of the Niagaran section extend farther eastward, but no equivalent to the Laurel limestone is present in the sections at Springfield, Yellow Springs, or Cedarville [i.e. southwestern Ohio], and the clayey section at those localities evidently is the northward extension of the Crab Orchard clays of southern Ohio and eastern Kentucky, and may not be the exact equivalent of the Osgood clay of Indiana." This interpretation was based, in part, upon Foerste's assumption that the entirety of the Laurel Formation of Indiana occupies a stratigraphical position below the base of the Euphemia Formation in western and southwestern Ohio, and at this point (1917) he began to doubt what he clearly must have thought earlier, specifically that the succession exposed in southwestern Ohio (e.g. Greene County) is nearly an exact equivalent of the Osgood-Laurel succession exposed in southeast Indiana.

By 1929, Foerste thought he had begun to sow the seeds of the answer to western and southwestern Ohio correlation. The introduction of the term Massie Formation (Foerste 1929), for what we now know is just his original Upper
Osgood Clay (see below and Fig. 4), brought a possible solution to the correlation conundrum. Through detailed study, primarily in Greene County, Ohio, Foerste began to realize that the Massie Formation shares a similar macrofauna with that of the Waldron Formation of Indiana (the unit above his original Laurel Formation). The similarity was so striking in fact, that by 1931, he was using the term Waldron Formation in Ohio to refer to the unit that he earlier named the Massie Formation (Foerste 1931, p. 173). His 1935 regional summary reinstated the name Massie for southwestern Ohio (Foerste 1935), but re-asserted the Massie as being a Waldron equivalent. Therefore, if the Massie truly is a Waldron equivalent, Foerste logically argued that whatever limestone rests immediately below the Massie should be named "Laurel" as it is in Indiana (Foerste 1931, 1935). This was the origin of the southwestern Ohio application of the term Laurel Formation, as a unit that rests above the Osgood Formation and below the Massie Formation (Slucher 2004, Slucher et al. 2006, Schumacher et al. 2012).

The major advancement in Ohio stratigraphy in this interval results from the fact that we now know that the Massie Formation is a synonym of Foerste's original Upper Osgood Clay/Shale in Indiana, and is not equivalent to the Waldron of Indiana. Recent detailed integrated stratigraphical studies of the Tristate area, and southwestern Ohio in particular (e.g. McLaughlin et al. 2008, Cramer 2009, Kleffner et al. 2012b), including new high-resolution sequence stratigraphy, conodont biostratigraphical data and $\delta^{13} \mathrm{C}_{\text {carb }}$ chemostratigraphy, have demonstrated that the Massie Formation, a clearly Sheinwoodian stratigraphical unit, does not correlate with the Waldron, a clearly Homerian stratigraphical unit currently placed as a member of the Pleasant Mills Formation in Indiana (Droste \& Shaver 1982, Shaver et al. 1986).

In its type area of Greene County, Ohio, the Massie Formation contains the conodont Kockelella walliseri (Kleffner 1994; see below), as well as the descending limb of the early Sheinwoodian $\delta^{13} \mathrm{C}_{\text {carb }}$ excursion (Cramer 2009, p. 96), suggesting a roughly middle Sheinwoodian position for the Massie Formation (Cramer et al. 2010a, 2010b, 2011). In contrast, the Waldron contains the middle Homerian $\delta^{13} \mathrm{C}_{\text {carb }}$ excursion (Cramer et al. 2006; Cramer 2009 , p. 111) and may actually be equivalent to the Greenfield Formation in western and southwestern Ohio (Droste \& Shaver 1982; Cramer 2009, p. 92; Kleffner et al. 2012b). If this is the case, then the Waldron-equivalent in Ohio (Greenfield) is stratigraphically separated from the Massie by the Euphemia, Springfield, and Cedarville formations. It is for this reason that we suggest future integration of the terms Euphemia, Springfield, and, possibly, Cedarville as members into the Laurel Formation to allow a common nomenclature throughout the region. However, there is some evidence for a disconformity between the Cedarville and underlying units at which the Waldron may be cut out (see 
McLaughlin et al. 2008). Thus, formalization of these Ohio terms will have to await a more thorough treatment of the Laurel Formation and overlying strata than is presented here.

\section{Osgood-Laurel Formation stratigraphical revisions}

The equivalence of the Massie Shale of Ohio with the Upper Osgood Clay of southeast Indiana was not consistently recognized during most of the previous century and this was a principal source of stratigraphical confusion. Present recognition of this correlation greatly facilitates the revisions to Tristate Osgood-Laurel stratigraphical nomenclature presented in Fig. 3. The variable placement of the base of the Laurel Formation from state to state indicates that the overlapping portion of stratigraphy throughout the Tristate area (i.e. the middle and upper Osgood of Foerste 1897, Laurel subunits 1 and 2 in Kentucky, and the Laurel and Massie formations of Ohio) requires some nomenclatural housekeeping in order to provide a consistent set of unit names that can be used across state-lines. The proposed changes to stratigraphical nomenclature are as follows.

1) The name Massie Formation should be extended throughout the study area to refer to the units previously designated as Upper Osgood Clay in Indiana (Foerste 1897), subunit 2 of the Laurel Formation in Kentucky (Peterson 1986), and the "Osgood Formation" (in restricted sense) in western Ohio (e.g. Foerste 1935).

2) Use of the name Laurel Formation in western and southwestern Ohio (i.e. Middle Osgood Limestone), as a unit that rests below the Massie Formation (i.e. Upper Osgood Clay of Indiana), is inappropriate with respect to the use of the term Laurel Formation in its type area of southeast Indiana, and requires revision.

3) The informal term Lewisburg was introduced by Kovach (1974) to refer to the Middle Osgood Limestone and is a viable replacement for the misused term Laurel Formation in Ohio. This unit would retain its current rank, in Ohio, of formation as the Lewisburg Formation throughout the Tristate area.

4) The term Osgood Formation will be applied in a Kentucky/Ohio sense to refer now only to the strata originally designated as the Lower Osgood Clay in Indiana (Foerste 1897). Restricting the use of Osgood in this manner allows us to deconvolute the nomenclature by introducing the names Lewisburg and Massie throughout the study area for the previously overlapping and confusing stratigraphical terms.

5) The proposed changes listed above would allow the base of the Laurel Formation to be placed at a consistent position throughout the Tristate area. This position is also consistent with the current base of the Laurel Formation in its type area of southeast Indiana and would represent the base of the Euphemia Formation, as presently recognized in Ohio. Formal integration of the Euphemia, Springfield and, possibly, Cedarville (formations in present Ohio usage) as members of the Laurel Formation must await future research.

In addition to the changes listed above, minor changes to the rank and geographical extent of the terms Dayton and Lee Creek are included below. What follows is a discussion of outcrops and quarries from Ohio, Indiana, and finally into west-central Kentucky that illustrate the through-going nature of these stratigraphical units. Finally, a brief compendium of revised nomenclature, presented stratigraphically, is included at the end of this report to provide an unambiguous record of the proposed changes.

\section{Ohio-Indiana-Kentucky Tristate stratigraphy}

\section{Cemex Quarry and John Bryan State Park, Greene County, Ohio}

The Cemex Quarry, located in northwestern Greene County, combined with John Bryan State Park, less than $11 \mathrm{~km}$ (seven miles) away in northern Greene County (see Schumacher et al. 2012), expose typical southwestern Ohio strata (Fig. 4) assigned here to the Brassfield, Dayton, Osgood, Lewisburg, Massie, and Laurel formations (Fig. 5). Cemex Quarry and John Bryan State Park serve as the revised type localities for the Dayton Formation (as revised in this report) and, of the localities included in this transect, are also the closest to the type area for the term "Massie", as defined by Foerste in 1929 (<16 km away, see Fig. 2).

The unit referred to as Dayton Formation in Greene County clearly matches the description presented by Norris et al. (1950), and is unequivocally the Dayton of southwestern Ohio (see Fig. 4 above). Here, we define the Dayton Formation in Greene County, Ohio (Fig. 5A), as a dense, glauconitic, dolomicrite that is tabular bedded with phosphatic staining and hardground surfaces throughout (see Revised Lithostratigraphical Terminology below). The Dayton is underlain by the Brassfield Formation and overlain by the Osgood Formation exclusively. Strata belonging to the Dayton Formation (as redefined herein) display two characteristics that can be used to identify true Dayton from calcareous Osgood higher up the arch. First, the Dayton Formation is much better indurated and is a more pure dolomicrite. Where the Osgood is more calcareous farther up the arch, its argillaceous character is betrayed by its fracture pattern after blasting (see Barrett Quarry below) or by its tendency to weather more easily than the overlying Lewisburg strata. Second, the Wenlock, the Dayton Formation, as defined herein, does not extend 

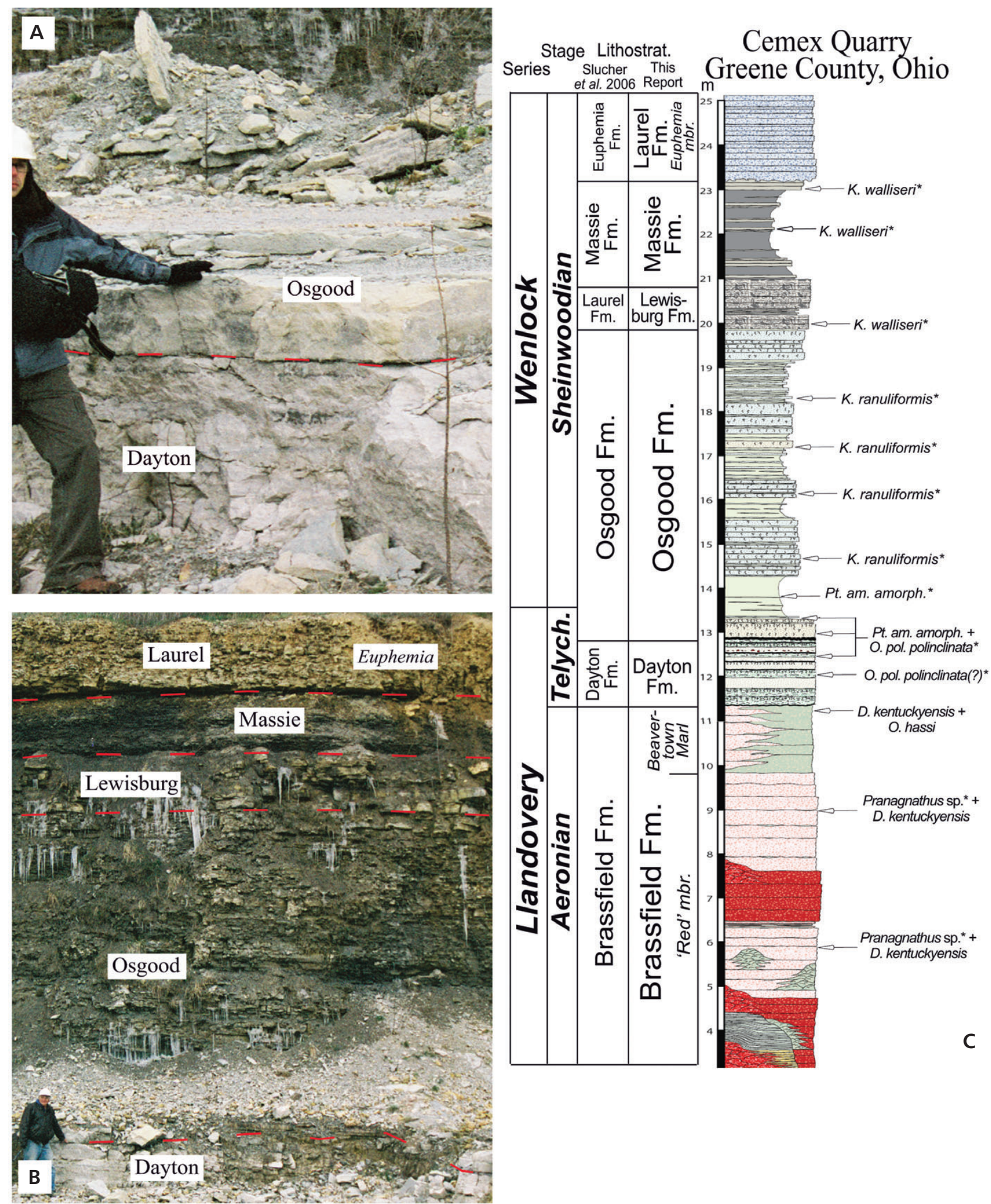

Figure 5. Photographs from Cemex Quarry (Panels A \& B), Greene County, Ohio, shown with the stratigraphic column from Cemex Quarry (modified from McLaughlin et al. 2008). Conodont data shown in Panel C with an asterisk following the species name denote that this species was recovered from John Bryan State Park (Kleffner 1994) and has been superimposed into the Cemex quarry stratigraphic column shown in Panel C. New conodont occurrences from Cemex Quarry (i.e. those without asterisks) come from Mark Kleffner (unpublished data). 

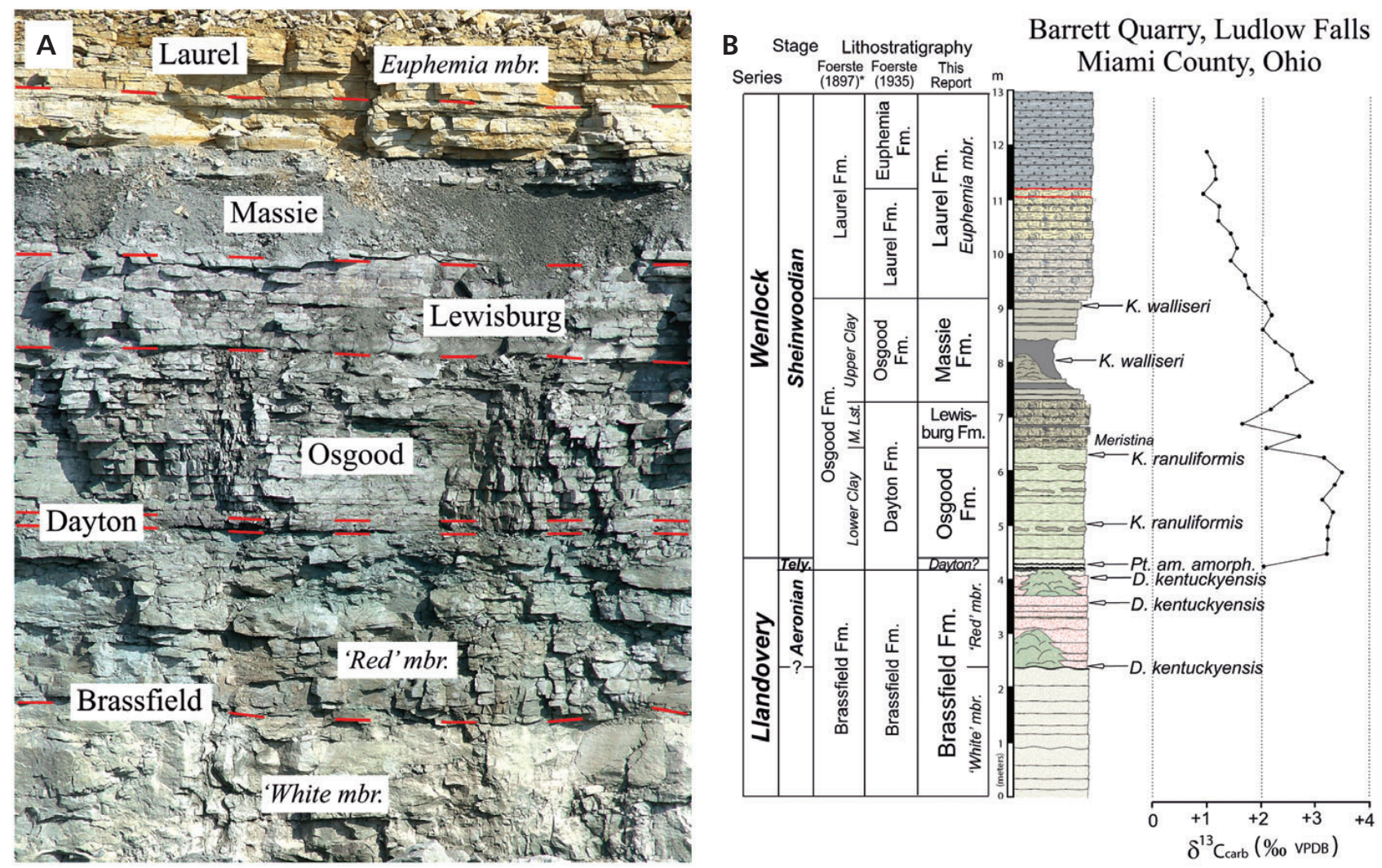

Figure 6. Photograph (Panel A) and stratigraphic column (Panel B) from Barrett Quarry, Miami County, Ohio (modified from McLaughlin et al. 2008). This far west in Ohio, the Dayton has thinned considerably and less than $1 \mathrm{~m}$ of strata (upper Brassfield-Dayton-lower Osgood) preserve an interval from the D. staurognathoides conodont biozone to the Lower K. ranuliformis conodont biozone (i.e. Aeronian Stage to lowermost part of the Sheinwoodian Stage). Here, the Osgood Formation is easily recognizable by the difference in material strength from the overlying Lewisburg Formation.

into the Wenlock. The Dayton Formation sensu stricto contains both Ozarkodina polinclinata polinclinata and Pterospathodus amorphognathoides amorphognathoides, as does the base of the overlying Osgood Formation (Fig. 5), indicating that the Dayton Formation is restricted to the middle (?) to upper part of the Telychian below the onset of the early Sheinwoodian $\delta^{13} \mathrm{C}_{\text {carb }}$ excursion.

The new conodont data from Cemex Quarry provided by Mark Kleffner, combined with the conodont data of Kleffner (1994) from the very similar succession at John Bryan State Park, help to demonstrate the magnitude of the unconformity between the Brassfield and the Dayton in southwestern Ohio. The presence of Distomodus kentuckyensis and Pranognathus sp. demonstrate an early to mid Aeronian age for the top of the Brassfield in Greene County, Ohio, and $O$. pol. polinclinata demonstrates a mid(?) to late Telychian age for the Dayton indicating that several million years are likely missing at this contact ( $c f$. Cramer et al. 2011). The base of the Sheinwoodian is located in the lower part of the Osgood Formation, just above the basal carbonate shown in Fig. 5A. Because the outcrops of John Bryan State Park have been exposed to the elements longer than those of Cemex Quarry, the differential weathering of the Osgood,
Lewisburg, and Massie formations is better developed at the park than in the Cemex Quarry high-wall (compare Fig. 5 with Schumacher et al. 2012). The Massie Shale exposed at Cemex Quarry and John Bryan State Park is unmistakably the Massie Shale first described from Greene County, Ohio, by Foerste (1929).

\section{Barrett Quarry, Miami County, Ohio}

The Barrett Quarry, located outside of the town of Ludlow Falls in Miami County, Ohio, serves as the first section in this transect that displays the typical succession of western Ohio. From this point westward into the first two tiers of counties in eastern and southeasternmost Indiana, the interval included in this investigation has remarkably little variation. This far west in Ohio (Miami County), the Osgood is thinner and better indurated and the Dayton here is, at best, a few centimetres thick (see Kleffner et al. 2012a). In the Barrett Quarry, the difference in material strength (shown by fracture patterns) between the Osgood and the Lewisburg formations is obvious (Fig. 6A). The early Sheinwoodian excursion is recorded in the Osgood-Massie interval 

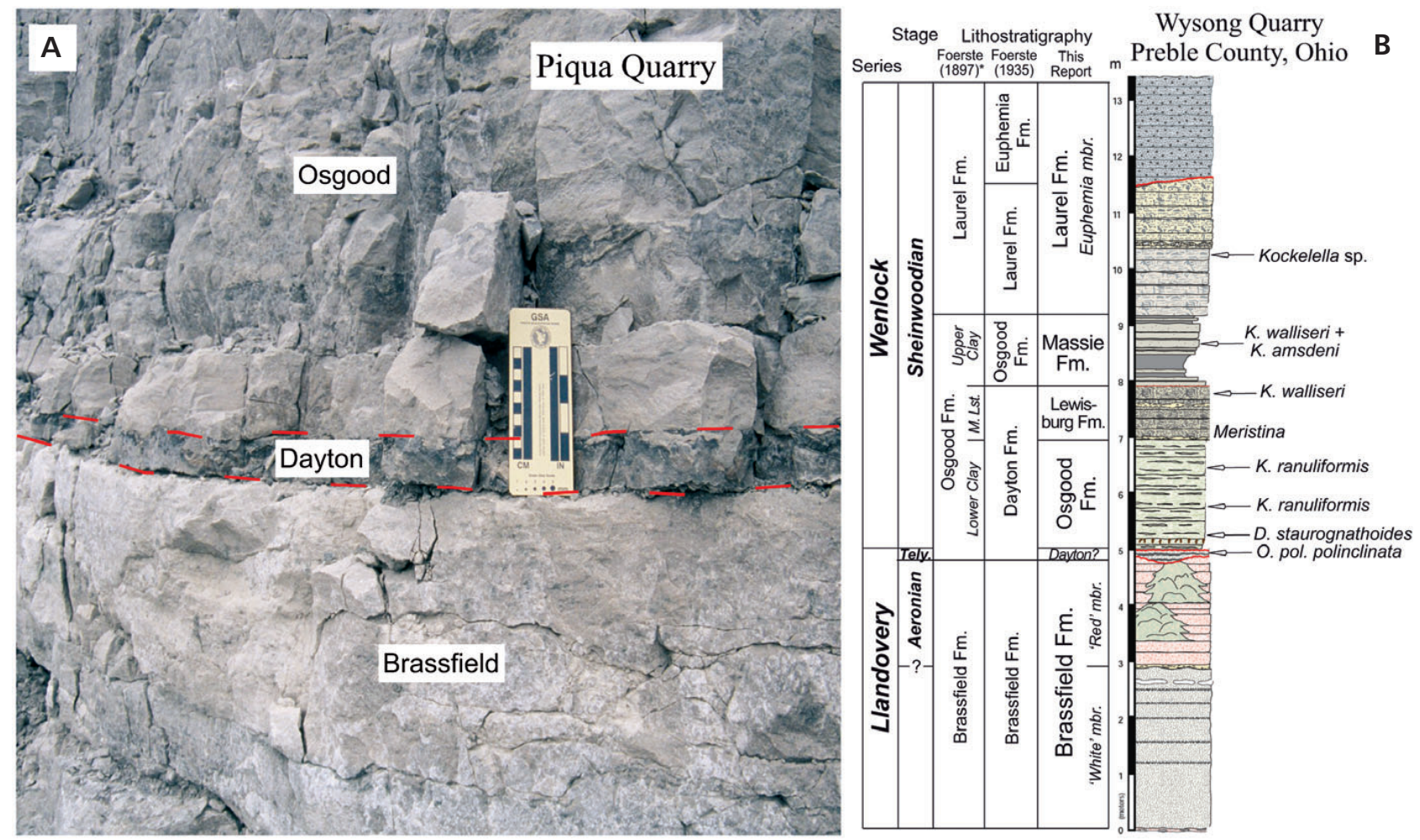

Figure 7. Photograph of Piqua Quarry, Miami County, Ohio (Panel A), and stratigraphical column (Panel B) from Wysong Quarry, Preble County, Ohio (modified from McLaughlin et al. 2008). Southwest from Miami County to Preble County, the stratigraphy is remarkably consistent (compare Panel B with Fig. 4B), however northwest from the city of Dayton, Ohio, the stratigraphy thins markedly. The Dayton Formation virtually disappears and the Osgood Formation becomes much more calcareous. Based upon conodont biostratigraphy and carbon isotope chemostratigraphy, the thin black phosphatic lag shown in Panel A is all that remains of the Dayton Formation to the north or west of Montgomery County, Ohio.

and values decline through the top of the Massie Formation, continuing down below $+2.0 \%$ into the Euphemia member of the Laurel Formation (revised usage here).

\section{Wysong Quarry, Preble County, Ohio}

The Wysong Quarry, located just south of the town of Lewisburg in Preble County, Ohio (Fig. 2), is $2.4 \mathrm{~km}$ (1.5 miles) south-southeast of the original type locality of the Euphemia (Foerste 1917) and serves as the type locality for the Lewisburg Formation. New and previously published conodont data from Kleffner (1994) are shown in Fig. 7B. Based upon physical stratigraphy, conodont biostratigraphy, and carbon isotope chemostratigraphy, there is extremely limited variability between the Piqua and Barrett quarries in Miami County, Ohio, heading southwestern to Wysong Quarry in Preble County, Ohio.

Moving northwest from Cemex and John Bryan in Greene County, Ohio (the revised type area of the Dayton Formation), toward the apex of the arch and thinner successions of western Ohio, the Dayton Formation (as redefined here) thins appreciably to the point where it virtually disappears (Kleffner et al. 2012a), being represented by only a few centimetres of extremely phosphate-rich or ironstained dolostone (Fig. 7A). For this reason, we suggest that the Dayton Formation extends slightly into Indiana as a thin reddish band at the base of the Osgood Formation, previously, but incorrectly, identified as the Lee Creek Member of the Brassfield Formation (see below).

It is important to note that throughout Greene, Miami, and Preble counties, it can be demonstrated quite clearly that the conodont biostratigraphy of the Osgood-LewisburgMassie succession in southwestern Ohio is identical to that in western Ohio. The Osgood Formation (our usage) contains Kockelella ranuliformis, indicative of an earliest Sheinwoodian age, whereas the Lewisburg Fm. and Massie Fm contain Kockelella walliseri indicative of mid to late Sheinwoodian age. Stable isotope $\left(\delta^{13} \mathrm{C}_{\text {carb }}\right)$ chemostratigraphy supports this correlation of the Osgood-Lewisburg-Massie succession to the lower-middle part of the Sheinwoodian Stage.

\section{Napoleon Quarry, Ripley County, Indiana}

The type area for the term "Osgood", as defined by Foerste (1897), is in and around the town of Osgood in Ripley 

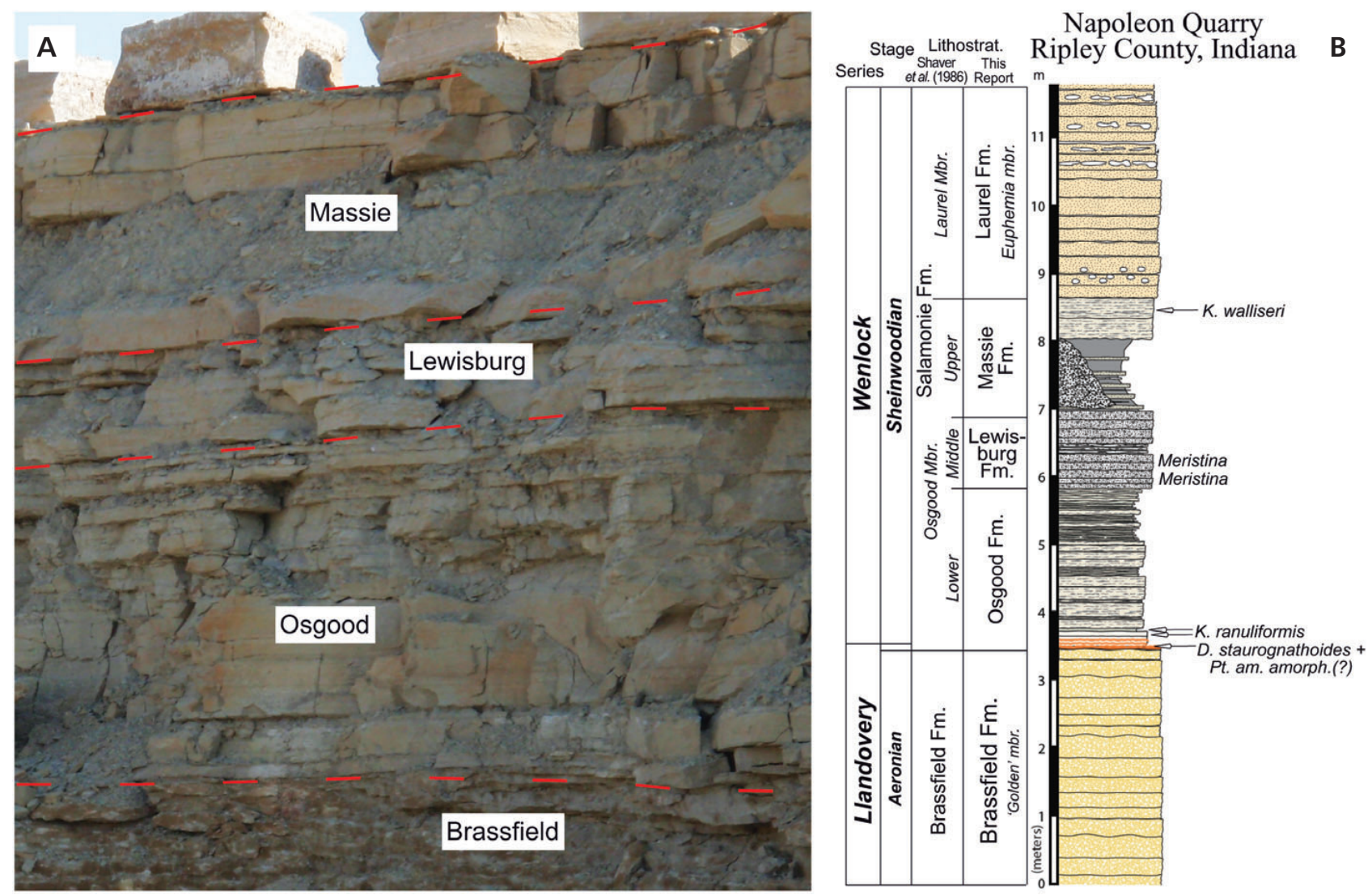

Figure 8. Photograph (Panel A) and stratigraphical column (Panel B) from Napoleon Quarry, Ripley County, Indiana (modified from McLaughlin et al. 2008). In this quarry, the "burrowed Laurel" is placed within the uppermost part of the Massie Formation (see text). Similarly, the basal carbonate unit of the Massie Formation is well exposed in this quarry and serves as the foundation for the small bioherms that protrude into the shales of the Massie Formation in this quarry.

County, Indiana. The Napoleon Quarry (Fig. 8) is located approximately $10 \mathrm{~km}$ (6 miles) north-northwest of the town of Osgood and, of the sections included in this study, it is the closest to Foerste's Osgood type area. From its type area (northwest-central Ripley County, Indiana), Foerste (1897) described a tripartite division of the Osgood Formation: a Lower Osgood Clay, a Middle Osgood Limestone, and an Upper Osgood Clay. The Napoleon Quarry clearly demonstrates the transition from Foerste's usage of Osgood (which is still used by the Indiana Geological Survey - although as a member of the Salamonie Formation; Shaver et al. 1986) to the restricted sense of the term presented here, as well as how the terms Massie and Lewisburg fit into Foerste's original classification. Herein, the term Osgood is restricted entirely to Foerste's Lower Osgood Clay. His Middle Osgood Limestone is effectively the Lewisburg Formation and the Massie Formation is effectively Foerste's Upper Osgood Clay.

It should be noted that herein we have chosen to place the top of the Massie at the point above which no further interbeds of shale occur. Occasionally, the interbedded upper part of the Massie (Foerste's "Burrowed Laurel") is preserved as a single or sometimes two beds of amalgamated burrow fills (Fig. 8A). In such cases, these galleries are included here within the Massie Formation. A more definitive statement about this boundary (top Massie-base Laurel) will have to await future revisions to the Laurel Formation.

Figure 8A shows the lower wall of the quarry, which exposes the entirety of Foerste's (1897) Osgood Formation. Nicoll \& Rexroad (1968) identified a thin carbonate unit between the Brassfield and Osgood in southeastern Indiana that they termed the "Lee Creek Member of the Brassfield Formation". They suggested that the Lee Creek Member could be traced as far north as Ripley and Decatur counties, occurring as a thin red band at the base of the Osgood (Fig. 8). As in western Ohio and mentioned earlier, however, based upon conodont biostratigraphy, these thin horizons are likely the westward equivalent of the Dayton Formation and not their Lee Creek Member (see below).

\section{Madison Roadcut, Jefferson County, Indiana}

The large roadcut on US 421, north of Madison, Indiana, serves as the best representative section for the revisions to 

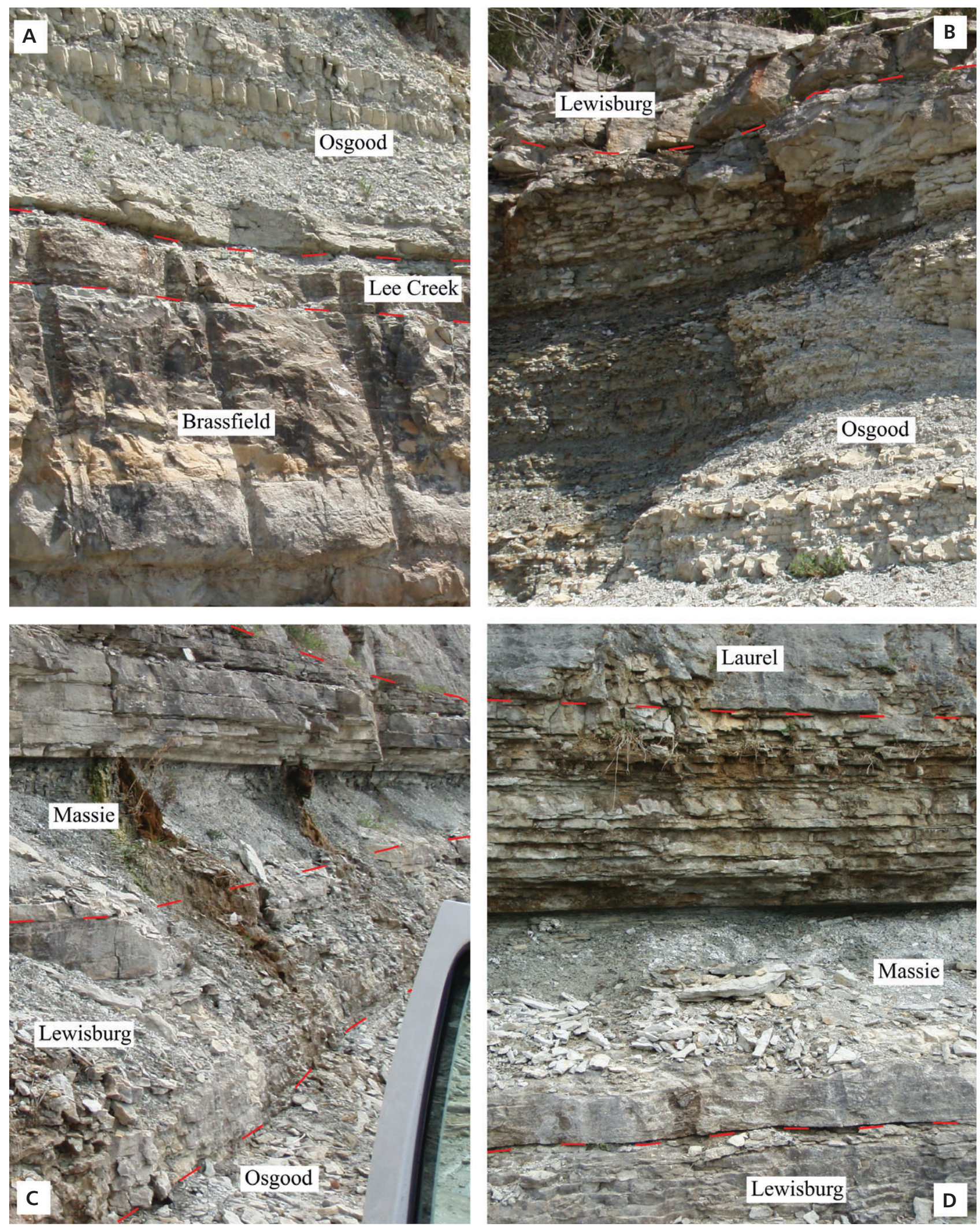

Figure 9. Photographs from the Madison Roadcut, Jefferson County, Indiana. The Lee Creek Formation (Panel A) is a clearly distinct unit from the underlying Brassfield Formation. As the Osgood thickens south from Ripley County into Jefferson County, the basal carbonate unit of the Osgood Formation become more readily identifiable (Panel A). This section is nominated here as a parastratotype for the Lewisburg and Massie formations (Panels C \& D). 
the terms used herein and displays strong similarities with the Cemex Quarry and John Bryan State Park. The section shows expansion relative to Napoleon Quarry and, as was the case with moving southeast from Preble and Miami counties in Ohio into Greene County, the first interval to begin thickening is the Osgood Formation (Fig. 9B). All of the units are thicker in southeast Indiana than higher up on the arch in the previous localities. The true Lee Creek Member is present for the first time (Fig. 9A) in this transect, and this locality is $\sim 16 \mathrm{~km}$ (10 miles) from the type section of the Lee Creek defined by Nicoll \& Rexroad (1968). The conodonts recovered from the Lee Creek Formation, identified by Nicoll \& Rexroad (1968) as Pterospathodus celloni, have since been reclassified by Männik (1998) as Pt. eopennatus indicating that the Lee Creek Formation correlates to a position within the middle part of the Telychian Stage. Although not recovered from this exposure, Nicoll \& Rexroad (1968) recovered Pt. eopennatus from several localities in Jefferson County, Indiana, all of which were within $13 \mathrm{~km}$ ( 8 miles) of this section. This is considerably below the higher Telychian position indicated by Pt. am. amorphognathoides and $O$. polinclinata polinclinata for the Dayton Formation of southwestern Ohio and represents stratigraphy not preserved at the unconformity between the Brassfield and the Dayton in Greene County, Ohio (e.g. Cemex Quarry).

Nicoll \& Rexroad (1968) designated the Lee Creek as a member of the Brassfield Formation; it is herein removed from the Brassfield and raised in rank to formation. In this section, however, the base of the overlying Osgood Formation is marked by a thin carbonate containing Pt. am. amorphognathoides and $O$. pol. polinclinata, exactly like the thin carbonate at the base of the Osgood Formation at Cemex Quarry in Greene County, Ohio. Therefore, in this section, there are no Dayton-equivalent strata. The older Lee Creek Formation appears to occupy this stratigraphical position (between the Brassfield and Osgood) throughout southern Indiana and west-central Kentucky.

This locality serves as the Indiana stratotype for the revised terminology presented here (Lee Creek, Osgood, Lewisburg, Massie, Laurel). The sharp surface separating the basal carbonate unit of the Massie Formation is well demonstrated at this locality (Fig. 9D). Conodonts recovered from Madison Roadcut (Fig. 10) were identified by Mark Kleffner (unpublished data). The presence of D. staurognathoides at the top of the Osgood in this section limits the uppermost part of the Osgood to, at highest, the Lower $K$. ranuliformis Zone.

\section{Crestwood, Oldham County, Kentucky}

The Crestwood section (referred to as Park Lake by McLaughlin et al. 2008) is located just northeast of the
Louisville metropolitan area in Oldham County, Kentucky. The Crestwood Composite contains the early Sheinwoodian $\delta^{13} \mathrm{C}_{\text {carb }}$ excursion (Fig. 10B), showing the same pattern as Barrett Quarry in Miami County, Ohio, with isotope values elevated and rising in the Osgood and declining through the top of the Massie Formation. The $\delta^{13} \mathrm{C}_{\text {carb }}$ data from Crestwood, Kentucky, and Barrett Quarry, Ohio, combined with the conodont data from Wysong Quarry and John Bryan State Park, Ohio, in addition to the physical stratigraphy provided throughout, demonstrate the reliability of the revised chronostratigraphical correlations within the study area of this report. As a result, we can resolve more than a century of stratigraphical confusion by applying a consistent stratigraphical terminology across the region.

\section{Revised regional lithostratigraphical terminology}

The revisions to Cincinnati Arch lithostratigraphical terminology presented in this report are summarized below for each state. A revised lithostratigraphical chart is provided for the Indiana-Kentucky-Ohio Tristate area (Fig. 11) that includes the currently accepted nomenclature in use in each state. We also present a brief compendium that includes the history, use, description and a few notes on correlation of the revised lithostratigraphical terms used herein.

\section{Southeastern Indiana}

The revisions made to the Telychian and Sheinwoodian strata of eastern and southeastern Indiana are shown in Fig. 11 and are summarized as follows: 1) The Lee Creek Member has been removed from the Brassfield Formation and raised in rank as the Lee Creek Formation. Temporally, the unconformity between the Lee Creek and the Brassfield is likely as significant, if not more so, than the unconformity between the Lee Creek and the overlying Osgood. 2) The term Osgood is restricted herein to the "Lower Osgood Clay" of Foerste (1897). 3) The term Lewisburg Formation is formally introduced as equivalent to the "Middle Osgood Limestone" of Foerste (1897). 4) The Massie Formation herein is Foerste's (1897) "Upper Osgood Clay" with the uppermost bed of his "Osgood Limestone" (our Lewisburg) marking the base of the Massie Formation. 5) The base of the Laurel Formation is herein defined as the point above which no further shale interbeds occur. If the beds in question are composed of amalgamated burrow gallery fillings, the base of the Laurel is placed at the top of the burrowed unit, making the previous term "Burrowed Laurel" the uppermost part of the Massie Formation herein. 

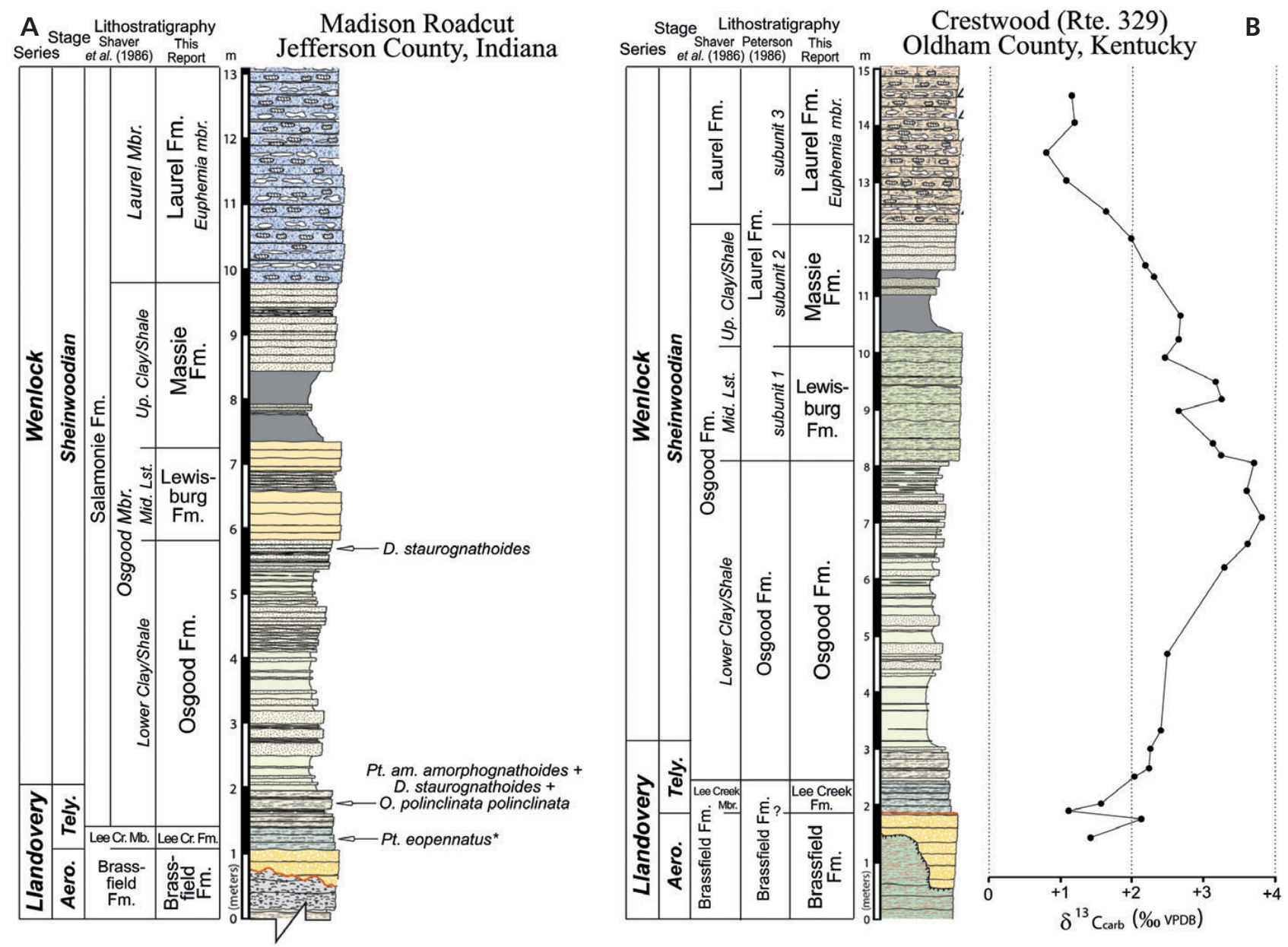

Figure 10. Stratigraphical columns for Madison Roadcut (Panel A), Jefferson County, Indiana, and Crestwood (Panel B), Oldham County, Kentucky (both modified from McLaughlin et al. 2008). Comparison between these two sections illustrates that the stratigraphical pattern see throughout this study continues southward into central Kentucky. Similarly, the carbon isotope profile from the Crestwood section confirms the correlation between the southernmost and northernmost areas of this study. Red wavy line at base of Brassfield in Ordovician-Silurian unconformity.

\section{West-Central Kentucky}

The revisions to the lithostratigraphical nomenclature of west-central Kentucky are comparatively minor, owing in large part to the fact that only two terms were presently in use (Osgood and Laurel). The revisions made to the definition of lithostratigraphical terms used in west-central Kentucky are presented in Fig. 11 and summarized as follows: 1) The term Lewisburg Formation should replace subunit 1 of the Laurel Formation (sensu Peterson 1986). 2) The term Massie Formation should replace Peterson's (1986) subunit 2 of the Laurel Formation. 3) The unit referred to as the Lee Creek Member of the Brassfield Formation is clearly recognizable, and for the reasons discussed above, should be removed as a member from the Brassfield, and similar to southern Indiana, should be recognized in west-central Kentucky as the Lee Creek Formation.

\section{Western and Southwestern Ohio}

The revised lithostratigraphical chart for western and southwestern Ohio is presented in Fig. 11, and the revisions made to the definition of lithostratigraphical terms used in this region are as follows: 1) The Dayton Formation redefined herein is restricted to a 0.5 to $2.5 \mathrm{~m}$-thick unit that overlies the Brassfield Formation and underlies the Osgood Formation in southwestern Ohio (E Montgomery, Greene, SW Clark counties). In western Ohio (Preble, NW Montgomery, Miami, and Darke counties), the term Dayton has historically been used to refer to the Osgood and Lewisburg formations of this report. The term Dayton is here restricted geographicalally to western and southwestern Ohio, and is used in its southwestern Ohio sense (see Dayton problem above), and is exclusively overlain by the Osgood Formation. Use of the term "Dayton Formation" in its previous western Ohio usage is herein abandoned. 2) In 


\begin{tabular}{|c|c|c|c|c|c|c|}
\hline $\begin{array}{c}\text { Foerste } \\
\text { (1897) } \\
\text { (E + SE Indiana) }\end{array}$ & $\begin{array}{l}\text { Shas } \\
(\mathrm{E}+\mathrm{S}\end{array}$ & $\begin{array}{l}\text { ver et al. } \\
1986) \\
\text { SE Indiana) }\end{array}$ & $\begin{array}{l}\text { Peterson (1986 } \\
\text { (WC Kentucky) } \\
\text { (Westem outcrop belt) }\end{array}$ & $\begin{array}{l}\text { 6) } \begin{array}{r}\text { Foerste } \\
(1935) \\
\text { (W Ohio) }\end{array}\end{array}$ & $\begin{array}{l}\text { Slucher (2004) } \\
\text { Schumacher } \\
\text { et al. (2012) } \\
\text { (Sw Ohio) }\end{array}$ & $\begin{array}{c}\text { This Report } \\
\text { (IN-KY-OH } \\
\text { Tristate Area) }\end{array}$ \\
\hline \multirow{2}{*}{$\begin{array}{l}\text { Laurel } \\
\text { Fm. }\end{array}$} & \multirow{5}{*}{ 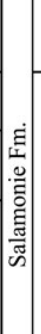 } & \multirow{2}{*}{$\begin{array}{l}\text { Laurel } \\
\text { Mbr. }\end{array}$} & \multirow{3}{*}{\begin{tabular}{|cc|}
$\mid \begin{array}{c}\text { subunit } \\
\text { Laurel }\end{array}$ \\
\cline { 2 - 3 } Fm. & $\begin{array}{c}\text { sub- } \\
\text { unit } \\
2\end{array}$ \\
\end{tabular}} & Euphemia Fm. & \multirow{2}{*}{$\begin{array}{l}\text { Euphemia } \\
\text { Fm. }\end{array}$} & \multirow{2}{*}{$\begin{array}{l}\text { Laurel Fm. } \\
\text { Euphemia mbr. }\end{array}$} \\
\hline & & & & Laurel Fm. & & \\
\hline \multirow{2}{*}{ U. Shale } & & \multirow{2}{*}{$\begin{array}{c}\text { U. Shale } \\
M . \\
\text { Limestone }\end{array}$} & & Osgood Fm. & Massie Fm. & Massie Fm. \\
\hline & & & subunit 1 & \multirow[b]{2}{*}{$\begin{array}{l}\text { Dayton } \\
\text { Fm. }\end{array}$} & Laurel Fm. & $\begin{array}{c}\text { Lewisburg } \\
\text { Fm. }\end{array}$ \\
\hline $\begin{array}{l}\text { Osgood } \\
\text { Fm. }\end{array}$ & & $\begin{array}{l}\text { Osgood } \\
\text { Mbr. } \\
\text { L. Shale }\end{array}$ & $\begin{array}{l}\text { Osgood } \\
\text { Fm. }\end{array}$ & & $\begin{array}{l}\text { Osgood } \\
\text { Fm. }\end{array}$ & $\begin{array}{c}\text { Osgood } \\
\text { Fm. }\end{array}$ \\
\hline & & & & & Dayton Fm. & Dayton Fm. \\
\hline
\end{tabular}

Figure 11. Summary of stratigraphical revisions to the Osgood-Laurel interval of the Tristate area including the original use of Osgood and Laurel (Foerste 1897), the currently accepted Indiana terminology (Shaver et al. 1986), the currently accepted terminology for west-central Kentucky (Peterson 1986), the historically important but currently disused terminology from western Ohio (Foerste 1935), the currently accepted terminology for Ohio, and the revisions proposed here shown at the far right. The through-going nature of these units across the study area illustrates that a simple and consistent terminology is both applicable and justified throughout the Indiana-Kentucky-Ohio Tristate area.

western Ohio, the Massie Shale has frequently been referred to as the entirety of the Osgood Formation in Ohio. This is clearly Foerste's (1897) "Upper Osgood Clay", and no longer is associated with the Osgood Formation, as redefined in this report. The term Massie Formation should replace the term "Osgood Formation" (used in a restricted sense) in western Ohio. 3) Use of the term Laurel within Ohio is redefined to match that of its type area in Indiana. The term and concept of "Laurel of Ohio" (e.g. Berry \& Boucot 1970) are here abandoned. 4) We formally introduce the term Lewisburg at the rank of formation to refer to strata previously assigned to the Middle Osgood Limestone in western Ohio (e.g. Kovach 1974) or the Laurel Formation in southwestern Ohio (Slucher 2004; Slucher et al. 2006; Schumacher et al. 2012). Throughout the study area of western and southwestern Ohio, this lithostratigraphical unit should be referred to as the Lewisburg Formation. 5) The Euphemia and Springfield, and possibly the Cedarville appear to occupy the same stratigraphical position as the Laurel of Indiana; middle Sheinwoodian to middle Homerian spanning the interval between the early Sheinwoodian and middle Homerian and positive $\delta^{13} \mathrm{C}_{\text {carb }}$ excursions. These Ohio units may make viable members of the Laurel Formation in the future; however, formalization of such changes is beyond scope of the current report and must await further study.

\section{Revised lithostratigraphy}

In the following sections we discuss the principal units of mid Telychian to early Sheinwoodian strata that overlie the
Brassfield Formation in southwestern Ohio, southeast Indiana, and west-central Kentucky. The units are discussed in approximate ascending chronostratigraphical order.

\section{Lee Creek Formation}

Type area and history. - Introduced by Nicoll \& Rexroad (1968) as the uppermost member of the Brassfield Formation in southeastern Indiana, the term Lee Creek is herein removed from the Brassfield and raised in rank to be the Lee Creek Formation. The type area and reference sections of Nicoll \& Rexroad (1968) are retained but its recognition is here restricted to the area south of central Ripley County, Indiana.

Description. - The Lee Creek Formation is underlain by the Brassfield Formation and overlain by the Osgood Formation and can be identified throughout southeastern Indiana and adjacent areas of Kentucky as a thin to lenticularbedded, orange-weathering, green to tan, phosphatic and glauconitic silty dolomudstone to dolocalcisiltite. The Lee Creek Formation is typically less than $1 \mathrm{~m}$ thick (often $<50 \mathrm{~cm}$ ), displays extensive bioturbation, and has an undulating, irregular, sharp lower surface that is often heavily mineralized. This irregular lower surface marks the contact between the Brassfield Formation and the Lee Creek Formation.

Correlation. - Conodonts recovered from the Lee Creek by Nicoll \& Rexroad (1968) have been reclassified by Männik (1998, 2007) as Pt. eopennatus in modern nomenclature indicating that the Lee Creek Formation correlates to a position within the middle part of the Telychian Stage. There are no Lee Creek-equivalent strata preserved on the Cincinnati Arch in eastern Indiana. Strata from Brown County in southern Ohio contain conodonts indicative of the Pt. eopennatus Superzone (M. Kleffner, unpublished data) and suggest that as one moves down ramp into the Appalachian Basin at least some Lee Creek-equivalent strata begin to come in (i.e. Waco Formation), but on the apex of the Cincinnati Arch throughout the study area of eastern Indiana and western Ohio, there are no strata that correlate with the Lee Creek Formation (see Kleffner et al. 2012a).

\section{Dayton Formation}

Type area and history. - The Dayton Formation was originally designated by Orton (1870) for strata exposed in the Dayton area of Montgomery County, Ohio. No type section was designated, and most of the original quarries that worked Orton's original "Dayton" are no longer accessible or have removed the exposed Dayton entirely. 
Orton originally suggested that the Dayton ranged from 5 to $50 \mathrm{ft}$ in thickness, and used the term to refer to what are now recognized to be a number of different lithostratigraphical units throughout Ohio.

Description. - The Dayton Formation as defined by Norris et al. (1950) referred to a unit in Greene County, Ohio, underlain by the Brassfield Formation and overlain by the Osgood Formation: "The Dayton is a hard white limestone about $8 \mathrm{ft}$. thick and occurs in thin, well-defined beds" (Norris et al. 1950). The Dayton, as defined herein, is a dense, white to pale, grey-green, glauconitic, tabular to thin-bedded dolomicrite that contains extensive phosphatic staining, phosphatic horizons, and pyrite throughout. Northwest of the revised type area in Greene County, the Dayton Formation thins rapidly and by western Miami County, Ohio, and Preble County, Ohio, the entire Dayton is represented by a thin, black-stained, phosphatic lag deposit $<10 \mathrm{~cm}$ thick fused to the base of the overlying Osgood (Kleffner et al. 2012a). By the Indiana border, this lag is represented by a red-stained interval at the base of the Osgood Formation that is $<5 \mathrm{~cm}$ thick.

Biostratigraphy and correlation. - Uppermost Dayton strata contain the conodonts Pterospathodus amorphognathoides amorphognathoides and O. polinclinata polinclinata indicating that the Dayton Formation does not extend into the Wenlock, and is restricted to the Telychian Stage of the Llandovery Series. The lower limit of the Dayton is not as well defined, but is no younger than middle Telychian in age. There is no Dayton equivalent in southeasternmost Indiana and adjacent Kentucky. Dayton strata sensu stricto contain $\delta^{13} \mathrm{C}_{\text {carb }}$ values between $+1.0 \%$ and $+2.0 \%$ o throughout the study area (Cramer 2009) below the onset of the early Sheinwoodian excursion.

Discussion. - The name Dayton has also been used to refer to strata as far to the east as western West Virginia that lie below the Estill Formation (e.g. Horvath 1969, Ryder 2006). As used prior to this report, the term Dayton therefore referred to a variety of strata occupying a variety of chronostratigraphical positions and representing a wide range of lithologies. Its only consistency in meaning was its stratigraphical position above the Brassfield and below either the Estill Formation or Osgood Formation. Herein, the type area of the Dayton is moved to Greene County (Cemex Quarry and John Bryan State Park), its definition is revised as a unit exclusively overlain by the Osgood Formation, and use of the term Dayton is returned nearly to the definition of Norris et al. (1950), which appears to be the oldest workable definition of a Dayton Formation in southwestern Ohio. The Dayton Formation as defined herein is not recognized southeast of northwestern Clinton County, Ohio or west of the easternmost tier of counties in Indiana.

\section{Osgood Formation}

Type area and history. - Introduced by Foerste (1897) and named for the town of Osgood in Ripley County, Indiana, the Osgood Formation has been recognized throughout much of the Laurentian mid-continent. Foerste's original use of the term included a "Lower Osgood Clay", a middle "Osgood Limestone", and an "Upper Osgood Clay". However, the term "Osgood" has not been equally applied. In western Ohio for instance, Foerste himself restricted his term Osgood Formation in Ohio (in its entirety) to refer exclusively to the "Upper Osgood Clay" of the Indiana type sections (Foerste 1935, p. 162), whereas in southwestern Ohio (e.g. Greene County) and west-central Kentucky, only the "Lower Osgood Clay" was referred to as the Osgood Formation.

Type and reference sections. - Exposures at Osgood, Indiana are presently poor and the Osgood Formation is only observable in tailings from the now water-filled Osgood Quarry. However, the interval is very well exposed farther south on an unnamed tributary of Indian-Kentuck Creek in southern Ripley County, Indiana, and at the large highway cuts on US Rte 421 north of Madison, in Jefferson County, Indiana (Madison Roadcut, Fig. 10A herein, also see McLaughlin et al. 2008). These sections serve as excellent surrogates for the incomplete sections at Osgood itself. Other excellent sections are seen in roadcuts on I-71 near rest areas on both the north and southbound lanes and nearby on Rte. 329 both north of Crestwood, Oldham County, KY (Fig. 10B herein, also see McLaughlin et al. 2008), and at the Cemex Quarry near Fairborn, Greene County, Ohio.

Thin calcareous lower to middle Osgood Formation, formerly termed "Dayton" in western Ohio (Foerste 1935), is well exposed at the Barrett Paving Quarry, Ludlow Falls, Ohio, the Wysong Stone Quarry at Lewisburg, Preble County, Ohio, the Napoleon Stone Quarry at Napoleon, Indiana and at New Point Stone Quarry, New Point, Indiana (Figs 6, 8, herein, also see McLaughlin et al. 2008).

Description. - The Osgood Formation, as revised herein, is underlain by the Lee Creek Formation in southeastern Indiana and adjacent Kentucky, by the Brassfield Formation in eastern Indiana, by a thin, phosphatic Dayton Formation typically $<10 \mathrm{~cm}$ thick in western Ohio, and by the Dayton Formation in the Dayton's revised type area of Greene County, Ohio. The Osgood Formation is overlain by the Lewisburg Formation throughout the study area. In southeastern Indiana, Foerste's original type area, the Osgood Formation (as revised here) is typically 3-4 m thick, consisting of what he referred to as "clay or clayey shale, varying locally to an argillaceous limestone, or even to thin layers of rubbly limestone" (Foerste 1897, p. 227). Across the study area, the Osgood Formation becomes much better 
indurated and begins to lose its shale character to the north (Foerste's rubbly limestone) and returns to the typical interbedded marlstones, dolocalcisiltites, dolowackestones, and olive-grey shales moving into southwestern Ohio and southeastern Indiana. In places, significant pyritization and rusty staining is found in distinct horizons within the upper part of the Osgood Formation in sections where the Osgood approaches its maximum thickness.

The Osgood Formation is a distinctive unit in weathered exposures because of its strikingly banded light and dark grey, rhythmic bedding. In its thickest areas near Dayton, Ohio or Mt. Washington, Kentucky, the Osgood is comprised of medium to dark grey, calcareous-dolomitic shaly mudstone interbedded with compact to crumbly argillaceous dolostones. The latter typically also show internal thin wavy laminae. A lower shale interval at Mt. Washington is red, maroon and green clay shale. In more proximal areas there is a gradual loss of shale until, in areas near Ludlow Falls, Ohio and Napoleon, Indiana, the interval comprises $80-90 \%$ argillaceous dolostone and the shales are reduced to relatively thin partings except for the basal few decimetres.

The carbonates are mainly dolomudstone to dolowackestone textures and less dolomitized outcrops show small comminuted debris of echinoderm plates and brachiopod fragments; whole fossils are generally uncommon but brachiopods, including Eoplectodonta and Atrypa are present on a few bedding planes. Recent studies have demonstrated abundant trace fossils on bedding planes in parts of the Osgood; these include Chondrites and Planolites. However, the unit is not so strongly bioturbated that the thin bedding is destroyed.

Biostratigraphy and correlation. - In thicker Osgood sections, the base of the formation is marked by a thin carbonate unit, which has a sharp lower contact and a gradational upper contact with the rest of the overlying Osgood Formation (informally referred to as the "basal Osgood carbonate" herein, Figs 5A and 9A, and Foerste 1931). Foerste's (1897) definition of a tri-partite Osgood identified the fact that in thicker sections, the base of the "Lower Osgood Clay" is typically marked by a thin carbonate interval (Foerste's 1897 "Lower Osgood Limestone" or his 1931 "Basal Osgood"). This carbonate and the first few centimetres of overlying strata, contain the conodonts Pt. amorphognathoides amorphognathoides as well as $O$. polinclinata polinclinata. The LAD of $O$. pol. polinclinata is just above this basal carbonate, which indicates that the base of the Osgood Formation is within the uppermost part of the Telychian Stage. The vast majority of the Osgood Formation however, correlates with the lowermost part of the Sheinwoodian Stage. In sections that contain a thinner Osgood, the Telychian is typically represented in the Osgood Formation by a few centimetres at most (Figs 6, 7). Both
Pt. am. amorphognathoides and $O$. pol. polinclinata have their LADs in lowermost Osgood strata, and the overlying strata contain the onset of the early Sheinwoodian $\delta^{13} \mathrm{C}_{\text {carb }}$ excursion.

Discussion. - The Osgood Formation has been designated as a member of the Salamonie Dolomite in southern Indiana (Pinsak \& Shaver 1964), and has been reduced in scope by mapping practice in Indiana and Kentucky. Herein, the term Salamonie Formation is discouraged south of the Laurel type area, and the term "Osgood" is promoted back to its previous status as the Osgood Formation throughout the Tristate area.

The use of the term "Osgood Formation", however, is herein restricted exclusively to the interval termed "Lower Osgood Clay" of southeast Indiana (Foerste 1897). In the Dayton region (SW Ohio) the name Osgood Formation has been applied in the Kentucky sense as only equivalent to the Lower Osgood Clay of Indiana; however, in western Ohio (e.g., Ludlow Falls, Lewisburg and New Paris), where the equivalent unit becomes thinner, more dolomitic and shows only thin shale partings, this interval has been termed "Dayton" and the name Osgood applied only to the shale herein identified throughout the region as the Massie Formation. This inconsistency of usage has caused much misunderstanding. We hope to cut through that confusion by applying the term Osgood consistently to a constrained interval of thinly bedded, fine-grained carbonates and shales or shale partings. Inasmuch as the same beds and bedsets are identifiable throughout the region despite changes in thickness and overall carbonate content we believe use of the same name in three states is advisable.

\section{Lewisburg Formation}

Type area and history. - Introduced informally by Kovach (1974) in Preble County, Ohio, to replace effectively Foerste's (1897) "Middle Osgood Limestone", the term has never been formally introduced and is not currently in widespread use. Reintroduced by McLaughlin et al. (2008) as Kovach (1974) used it, the term "Lewisburg" is utilized by this report and is similarly given formational rank. The Lewisburg Formation as defined here is nearly equivalent to its original use (to replace Foerste's "Middle Osgood Limestone") with the exception of the uppermost bed of Foerste's Osgood Limestone and Kovach's Lewisburg (often with a distinct surface at its base, Fig. 9D) being removed and referred to herein as belonging to the overlying Massie Formation throughout the study area.

Description. - The Lewisburg Formation is underlain by the Osgood Formation (as revised herein) and is overlain by the Massie Formation (as revised herein). Foerste 
(1897) described what is now termed the Lewisburg Formation as follows: "Above the Lower Osgood clay bed or its equivalents [Osgood Formation herein]..., there is almost everywhere a layer or number of layers of limestone, very crinoidal in character, and usually presenting fossils on its upper surface and in the intercalated clay beds" (Foerste 1897, p. 229). The years of field work leading to the publication of McLaughlin et al. (2008) included a major effort to trace this formation throughout the current study area. The type section for the Lewisburg Formation is herein placed at the Wysong Quarry, just south of the town of Lewisburg in Preble County, Ohio. McLaughlin et al. (2008) described the Lewisburg Formation from its revised type section as " $\sim 1 \mathrm{~m}$ of amalgamated, dolomitic packstone-grainstone divided in half by $\sim 10 \mathrm{~cm}$ of gray shale and thin, lenticular, fine-grained grainstones... ...Macrofossils are difficult to identify in this unit and are composed mostly of crinoid columnals...". The parastratotype for the Lewisburg is placed at the Madison Roadcut in Jefferson County, Indiana (Fig. 9C).

The Lewisburg Formation is comprised of pale grey- to beige-weathering fossiliferous dolostone or limestone about $0.5 \mathrm{~m}$ to $4 \mathrm{~m}$ thick. In many localities across southeastern Indiana the Lewisburg Formation comprises coarse echinoderm pack- to grainstone. The brachiopods Atrypa and Meristina (formerly Cryptothyrella) cylindrica are particularly typical of the Lewisburg interval. Throughout much of its outcrop, the Lewisburg is tripartite (Fig. 9C), with a lower generally medium to thick bedded compact dolo-wacke to packstone, a middle argillaceous and nodular interbedded mudstone/dolostone, and an upper fossiliferous limestone/dolostone. Generally, this interval is more fossiliferous than underlying strata.

The basal unit, informally unit A, is pale yellowish grey and weathers pale buff. In certain localities, notably near Dayton, Ohio the basal unit is vuggy and displays moulds of brachiopods and crinoid debris. The middle division, unit B, of the Lewisburg Formation is generally more argillaceous and typically weathers as irregularly bedded nodular to rubbly limestone/dolostone with much interbedded medium grey mudstone. The upper or $\mathrm{C}$ division of the Lewisburg Formation is more compact, typically about $0.5 \mathrm{~m}$ to $1 \mathrm{~m}$ thick and is typically the most fossiliferous unit of the formation. In places this interval is depressed and slightly deformed underneath local micritic bioherms that extend into the overlying Massie Shale. The Lewisburg Formation is relatively thin toward the northern extent of the study area in Indiana, and western Ohio and the tripartite nature of the unit becomes somewhat obscured, although a more compact top bed is almost always recognizable.

Biostratigraphy and correlation. - The base of the Lewisburg is within the Upper $K$. ranuliformis Conodont Zone and above the onset of the early Sheinwoodian $\delta^{13} \mathrm{C}_{\text {carb }}$ excursion. The stratigraphically important conodont $K$. walliseri first occurs in the study area within the Lewisburg Formation indicating an early-mid Sheinwoodian age (see Cramer et al. 2010b).

Discussion. - Kovach (1974) introduced the term "Lewisburg" to refer to Foerste's "Middle Osgood Limestone", and Kovach's use is essentially retained herein. We herein resurrect this name as a formation-scale unit to be applied at least from Greene County, Ohio westward to the first two tiers of counties in southeast Indiana and from there, south through west-central Kentucky. The strata herein termed Lewisburg correspond to a portion of what was referred to in much past literature as "Laurel of Ohio" (e.g. Foerste 1929, Berry \& Boucot 1970, Slucher 2004, Slucher et al. 2006, Schumacher et al. 2012) from John Bryan State Park northwestward to near the Indiana State line. In Indiana, the interval has generally been referred to as the "Middle Limestone" of the Osgood (Foerste, 1897), even though it is generally a dolostone. In Kentucky, the name Lewisburg Formation should replace subunit 1 of the Laurel Formation (Peterson 1986).

\section{Massie Formation}

Type area and history. - Introduced by Foerste (1929) to refer to the medium to dark grey shales underlying the Euphemia Formation exposed along Massie Creek, west of the town of Cedarville in Greene County, Ohio, the term Massie is in current use at the rank of formation within Ohio (Slucher 2004, Slucher et al. 2006) as the Massie Formation, and formational rank is retained herein. As a replacement for Foerste's (1897) "Upper Osgood Clay", the Massie Formation can be identified throughout the present study area as the upper Osgood of Indiana, the Osgood of western Ohio, subunit 2 of the Laurel Formation in Kentucky, or the Massie Formation in southwestern Ohio. Herein the name is extended from the type area in Greene County, Ohio, northwest at least as far as the exposures at Ludlow Falls, Lewisburg and New Paris, Ohio at the state line and thence westward into Indiana at least to Decatur County, Indiana, and southward through west-central Kentucky at least as far as the Louisville area.

Description. - The Massie Formation is underlain by the Lewisburg Formation, and overlain by the informal Euphemia member of the Laurel Formation (see Laurel entry below). The Massie Formation in Foerste's original type area (Greene County, Ohio) is typically a 2 m-thick dark grey calcareous shale with thin, lenticular, argillaceous dolowackestones and dolocalcisiltites. This dark grey shale facies represents the majority of the Massie Formation throughout the study area. However, the base of the Massie 
Formation, as defined herein, is a thin carbonate unit with a typically distinct lower surface separating it from the underlying Lewisburg Formation (Fig. 9D). The top of the Massie Formation is defined here by the base of the Laurel Formation, which has been placed at the position above which no further interbedded thin, tabular dolostone and dolomitic shales occur. In the event that the beds in questions are amalgamated burrow galleries (i.e. the so-called burrowed Laurel), the base of the Laurel (and top of the Massie) is placed at the top of these beds.

At its type section, near Cedarville, Ohio, the Massie Shale attains thicknesses of up to $3 \mathrm{~m}$ and is a fossiliferous grey shale; in the Wysong Quarry at Lewisburg, Ohio, the Massie Shale is composed of approximately $1 \mathrm{~m}$ of dark grey dolomitic shale and tan, thin to medium bedded dolocalcisiltites to dolomarlstones. Rusty spotting occurs locally within the grey shales. At Napoleon Quarry the Massie is composed of approximately $1 \mathrm{~m}$ of dark to medium grey, dolomitic shales and light grey dolocalcisiltites and dolowackestones. This unit contains a relatively diverse fauna that is notable for its diverse echinoderm faunas, including a high diversity of diploporitan cystoids, coronoids, one of the youngest eocrinoids and the youngest known paracrinoids (see Frest et al. 1999, 2011).

Biostratigraphy and correlation. - The Massie Formation contains the conodont Kockelella walliseri and the falling limb of the early Sheinwoodian $\delta^{13} \mathrm{C}_{\text {carb }}$ excursion indicating a mid Sheinwoodian age for this unit. $\delta^{13} \mathrm{C}_{\text {carb }}$ values decline to below $+2.0 \%$ across the contact between the Massie Formation and the overlying Laurel Formation throughout the study area marking the end of the excursion.

Discussion. - A wide variety of different names have been applied to this shale unit despite its consistent lithology and similar thicknesses over a very large region. Foerste (1897) referred to this shale informally as the "soapstone beds" in southeastern Indiana, but subsequently assigned it to the upper shale division of the Osgood Formation; this term (soapstone beds) has been used informally in SW Indiana where the Osgood was subsequently assigned as a member of the overly broad Salamonie Dolomite. The Massie Formation is nearly an exact replacement for Foerste's (1897) "Upper Osgood Clay". In the area of Ludlow Falls, Ohio, the Massie has been simply called "Osgood Shale", whereas in the Louisville area of Kentucky the unit has been mapped as subunit 2 of the Laurel Formation (Peterson 1986).

\section{Laurel Formation}

Type area and history. - Foerste (1896) originally used the term "Laurel dolomite" for the strata between the Brassfield (his Clinton) and the Waldron Shale, exposed near Laurel in Franklin County, Indiana. However, the following year Foerste (1897) introduced the term Osgood for some of these strata and reduced the term Laurel to nearly its present use in Indiana. The term was applied quite differently in Ohio and Kentucky (oddly enough, knowingly by Foerste himself) and these alternative uses are abandoned herein. The reader should consult the Lewisburg and Osgood entries for details regarding how the term "Laurel" was previously applied outside of Indiana. Herein, the term Laurel (as originally defined in Indiana) is preserved in this report, nearly as defined by Foerste (1897). Bringing the Ohio use of the term Laurel into alignment with the type area of the Laurel in Indiana and abandoning the term and concept of "Laurel of Ohio", the interval partly or wholly equivalent to the Laurel Formation in its type area is represented by a number of named units in Ohio, the lowest of which is the Euphemia Formation. Further research will be required to integrate this stratigraphical interval, and other than to redefine the base of the Laurel Formation, this unit is not revised by this report.

Description. - As revised herein, the Laurel Formation is underlain by the Massie Formation throughout the study area, and is overlain by the Limberlost Member of the Pleasant Mills Formation in Indiana (Droste \& Shaver 1982), the Waldron Formation in Kentucky (Peterson 1986), and, possibly, the Greenfield Formation in Ohio (see Droste \& Shaver 1982 and Kleffner et al. 2012b). Foerste (1897) placed its lower contact at the first good carbonates above the shales of the Massie Formation (his "Upper Osgood Clay"). These lowermost beds that are often heavily burrow-mottled, that contain shale interbeds of the underlying Massie Formation, and that are occasionally preserved as a single lithological unit in a series of filled Thalassinoides-type burrow galleries, are included here within the underlying Massie Formation. Therefore, the base of the Laurel Formation is here revised to the point at which no further shale interbeds are present or, where the beds in question are amalgamated burrow galleries, the base of the Laurel Formation is placed at the top of these galleries.

Correlation. - The base of the Laurel Formation, as revised herein, is clearly above the FAD of the conodont Kockelella walliseri as well as showing the descending limb of the early Sheinwoodian excursion indicating a mid to late Sheinwoodian age for this contact. The $\delta^{13} \mathrm{C}_{\text {carb }}$ record of the Laurel Formation is characterized by continued decreasing $\delta^{13} \mathrm{C}_{\text {carb }}$ values at its base in the first metres above the Massie Formation and then remains at roughly stable flat-line values up-section (Cramer 2009). 


\section{Salamonie Formation}

Type area and history. - The term Salamonie was erected by Pinsak \& Shaver (1964) for use in eastern and northeastern Indiana where Foerste's (1897) Osgood becomes more calcareous and more difficult to separate from the overlying Laurel. Therefore, to retain these terms (Osgood and Laurel) they were demoted to member status within the newly defined Salamonie Formation. The term "Salamonie" is herein considered an unneccesarily over-lumped term that precluded formal introduction of the terms Lewisburg and Massie by this report, and therefore we suggest either that the term Salamonie be raised to group status (but this would conflict with the older and more widely used terms Clinton and Lockport at the group level in North America - see Cramer et al. 2011), or more simply, that the term Salamonie Formation be restricted to use north of the present study area.

Correlation. - The term, as originally defined, referred to strata now included within the Osgood, Lewisburg, Massie, and Laurel formations in their entirety. The term was never offically recognized in Ohio.

\section{Conclusions}

The present investigation demonstrates the lateral continuity of major units assigned to the Telychian to middle Sheinwoodian stages of the mid-continent of Laurentia. Revisions to the lithostratigraphical terms Lee Creek, Dayton, Osgood, Lewisburg, Massie and Laurel are summarized as follows:

1) The Lee Creek is no longer a member of the Brassfield and is raised here to formational status.

2) The definition of the Dayton Formation is revised, its geographical extent is restricted, and its type area is placed in Greene County, Ohio.

3) The term Osgood is re-elevated to formation status, but its meaning is restricted to Foerste's (1897) "Lower Osgood Clay", matching present use in west-central Kentucky and southwestern Ohio.

4) The term Lewisburg Formation is formally introduced here to replace Foerste's (1897) "Middle Osgood Limestone" in Indiana, the Laurel Formation of southwestern Ohio, and subunit 1 of the Laurel Formation in Kentucky.

5) The term Massie is elevated to formation rank and is extended geographically to replace effectively Foerste's (1897) "Upper Osgood Clay" in Indiana, the Osgood Formation in western Ohio, and subunit 2 of the Laurel Formation of Kentucky.

6) The term and concept of "Laurel of Ohio" (e.g. Berry $\&$ Boucot 1970) are herein abandoned.
7) We suggest that the Euphemia and Springfield, and possibly Cedarville are, together, equivalent to the Laurel of Indiana, and future integration of these Ohio units as members of the Indiana Laurel Formation should be pursued.

The units recognized herein persist with similar thicknesses, lithologies, and faunas, through a large region of the Tristates area (Ohio, Indiana, Kentucky) that is roughly delimited to the north as far as the first tier of counties north of Dayton, Ohio, southeastward to about Cedarville, Ohio, northwestward to New Point, Indiana and southward along the Arch through west-central Kentucky. These points delimit a roughly rectangular area oriented NNE to SSW with approximate dimensions of $300 \mathrm{~km}$ north to south and about $100 \mathrm{~km}$ east to west or something approaching 30,000 sq. $\mathrm{km}$.

Over this entire region, all available exposures and drill cores show remarkable consistency and suggest both that the vertical stratigraphical patterns were produced by regional, allocyclic forcing and that the area delimited above comprised a NNE-SSW elongate belt of roughly similar environments, approximately parallel to depositional strike. The general thinning of the Osgood Formation and enhanced erosion along the axis of the arch suggests a transition from slightly deeper areas to both the southwest and southeast onto a relative high in eastern Indiana and western Ohio.

\section{Acknowledgements}

We thank Greg Schumacher at the Ohio Geological Survey Core Facility for providing access to invaluable core suites and we are also indebted to the numerous quarry owners, managers and operators throughout the study area. In addition, this paper has benefitted greatly from reviews by Ernie Slucher, United States Geological Survey, and Markes Johnson, Williams College. This work arose from nearly a decade of intense restudy of Silurian mid-continent stratigraphy and has been partially funded during that time by a Paul Sander Grant from the Cincinnati Dry Dredgers to J.R.T., a Presidential Fellowship from The Ohio State University to B.D.C., NSF Earth Sciences Post-Doctoral Fellowship EAR-0948277 to B.D.C., NSF Grant EAR-0518511 to C.E.B. and Warren Huff, and NSF Grant EAR-0517929 to M.A.K. \& James E. Barrick. This work is a contribution to the International Geoscience Programme (IGCP) Project No. 591 - The Early to Middle Paleozoic Revolution (www.igcp591.org).

\section{References}

Berry, W.B.N. \& Boucot, A.J. 1970. Correlation of North American Silurian Rocks. Geological Society of America Special Paper 102, 1-289.

BRETT, C.E. \& RAY, D.C. 2005. Sequence and event stratigraphy of Silurian strata of the Cincinnati Arch region: Correlations 
with New York-Ontario successions. Proceedings of the Royal Society of Victoria 117, 175-198.

Cramer, B.D. \& Saltzman, M.R. 2005. Sequestration of ${ }^{12} \mathrm{C}$ in the deep ocean during the early Wenlock (Silurian) positive carbon isotope excursion. Palaeogeography, Palaeoclimatology, Palaeoecology 219, 333-349.

DOI 10.1016/j.palaeo.2005.01.009.

Cramer, B.D., Kleffner, M.A. \& Saltzman, M.R. 2006. The late Wenlock 'Mulde' positive carbon isotope excursion in North America. GFF 128, 85-90.

DOI 10.1080/11035890601282085

Cramer, B.D. 2009. Chapter 4: Chronostratigraphic correlation of Telychian-Homerian units across the Cincinnati Arch: Recalibrating the Silurian strata of the American midcontinent, 66-128. In CRAMER, B.D. Application of Integrated High-Resolution Biochemostratigraphy to Paleozoic Chronostratigraphic Correlation: Recalibrating the Silurian System. Ph.D. dissertation, The Ohio State University, Columbus.

Cramer, B.D., Brett, C.E., Melchin, M.A., Männik, P., KlefFNer, M.A., McLaughlin, P.I., Loydell, D.K., Munnecke, A., Jeppsson, L., Corradini, C., Brunton, F.R. \& Saltzman, M.R. 2011. Revised correlation of the Silurian System of North America with global and regional chronostratigraphic units and $\delta^{13} \mathrm{C}_{\text {carb }}$ chemostratigraphy. Lethaia 44, 185-202. DOI 10.1111/j.1502-3931.2010.00234.x

Cramer, B.D., Kleffner, M.A., Brett, C.E., McLaughlin, P.I., Jeppsson, L., Munnecke, A. \& SAmtleben, C. 2010b. Paleobiogeography, high-resolution stratigraphy, and the future of Paleozoic biostratigraphy: Fine-scale diachroneity of the Wenlock (Silurian) conodont Kockelella walliseri. Palaeogeography, Palaeoclimatology, Palaeoecology 294, 232-241. DOI 10.1016/j.palaeo2010.01.002

Cramer, B.D., Loydell, D.K., SAmtleben, C., Munnecke, A., Kaljo, D., Männik, P., Martma, T., Jeppsson, L., KlefFner, M.A., Barrick, J.E., Johnson, C.A., EMsBo, P., JoAChimski, M.M., Bickert, T. \& SALtZMAn, M.R. 2010a. Testing the limits of Paleozoic chronostratigraphic correlation via high-resolution $(<500,000 \mathrm{yrs})$ integrated conodont, graptolite, and carbon isotope $\left(\delta^{13} \mathrm{C}_{\text {carb }}\right)$ biochemostratigraphy across the Llandovery-Wenlock (Silurian) boundary: Is a unified Phanerozoic timescale achievable? Geological Society of America Bulletin 122, 1700-1716. DOI 10.1130/B26602.1

Droste, J.B. \& Shaver, R.H. 1982. The Salina Group (Middle and Upper Silurian) of Indiana. Indiana Geological Survey Special Report 24, 1-41.

FoERSTE, A.F. 1896. An account of Middle Silurian cores of Ohio and Indiana. Cincinnati Society of Natural History Journal 18, 161-200.

FoERSTE, A.F. 1897. A report on the geology of the Middle and Upper Silurian rocks of Clark, Jefferson, Ripley, Jennings, and southern Decatur Counties, Indiana. Indiana Department of Geology and Natural Resources Annual Report 21, 213-288.

FoERSTE, A.F. 1906. The Silurian, Devonian, and Irvine formations of east-central Kentucky, with an account of their clays and limestones. Kentucky Geological Survey Bulletin 7, 1-369.

Foerste, A.F. 1917. Notes on Silurian fossils from Ohio and other central states. Ohio Journal of Science 17, 187-204.

Foerste, A.F. 1929. The correlation of the Silurian section of Ad- ams and Highland Counties with that of the Springfield area. Ohio Journal of Science 29, 168-169.

Foerste, A.F. 1931. The paleontology of Kentucky: III, Silurian fauna. Kentucky Geological Survey Bulletin 36, 236-320.

FoERste, A.F. 1935. Correlation of Silurian formations in southwestern Ohio, southeastern Indiana, Kentucky, and Tennessee. Bulletin of the Scientific Laboratories of the University of Denison 30, 119-205.

Frest, T.J., Brett, C.E. \& Witzke, B.J. 1999. CaradocianGedinnian echinoderm associations of central and eastern North America, 638-783. In Boucot, A.J. \& Lawson, J.D. (eds) Palaeocommunity Analysis: A Silurian-Lower Devonian Example. Columbia University Press, New York.

Frest, T.J., Strimple, H.L. \& Paul, C.R.C. 2011. The North American Holocystites fauna (Echinodermata: Blastozoa: Diploporita): Paleobiology and systematics. Bulletins of American Paleontology 380, 1-141.

Horvath, A.L. 1969. Relationships of Middle Silurian strata in Ohio and West Virginia. Ohio Journal of Science 69, 321-342.

KLEFFner, M.A. 1994. Conodont biostratigraphy and depositional history of strata comprising the Niagaran sequence (Silurian) in the northern part of the Cincinnati Arch region, west-central Ohio, and evolution of Kockelella walliseri (Helfrich). Journal of Paleontology 68, 141-153.

Kleffner, M.A., Cramer, B.D., Brett, C.E., Mikulic, D.G., Klussendorf, J. \& Johnson, T. 2012a. Lower Silurian of western Ohio - The case of the disappearing Dayton and unique Midwestern co-occurrence of pentamerid brachiopods with the Gravicalymene celebra Trilobite Association in the Springfield Formation, 1-18. In SANDY, M.R. \& Goldman, D. (eds) Geological Field Trips in Ohio and Kentucky. Geological Society of America Field Guide 27. DOI 10.1130/2012.0027(01)

KlefFner, M.A., Swift, R.J.A., Barrick, J.E. \& Karlsson, H.R. 2012b. Conodont biostratigraphy and $\delta^{13} \mathrm{C}$ chemostratigraphy of the Salina Group in North American Midwestern Basins and Arches Region (Western Ohio and Eastern Indiana). Geological Society of America Abstracts with Programs 44(5), 2.

Kovach, J. 1974. Stratigraphy and paleontology of the pentamerinid brachiopods of the Niagaran rocks of western Ohio and eastern Indiana. 366 pp. Ph.D. dissertation, The Ohio State University, Columbus.

MÄNNIK, P. 1998. Evolution and taxonomy of the Silurian conodont Pterospathodus. Palaeontology 41, 1001-1050.

MäNNıK, P. 2007. An updated Telychian (Late Llandovery, Silurian) conodont zonation based on Baltic faunas. Lethaia 40, 45-60. DOI 10.1111/j.1502-3931.2006.00005.x

McLaughlin, P.I., Cramer, B.D., Brett, C.E. \& KlefFner, M.A. 2008. Silurian high-resolution stratigraphy on the Cincinnati Arch: Progress on recalibrating the layer-cake, 119-180. In MARIA, A.H. \& CounTs, R.C. (eds) From the Cincinnati Arch to the Illinois Basin: Geological Field Excursions along the Ohio River Valley. Geological Society of America Field Guide 12. DOI 10.1130/2008.fld012(08).

NicColl, R.S. \& ReXroad, C.B. 1968. Stratigraphy and conodont paleontology of the Salamonie Dolomite and Lee Creek Member of the Brassfield Limestone (Silurian) in southeastern Indi- 
ana and adjacent Kentucky. Indiana Geological Survey Bulletin 40, 1-73.

Norris, S.E., Cross, W.P. \& Goldthwait, R.P. 1950. The water resources of Greene County, Ohio. Ohio Division of Water Bulletin 19, 1-52.

OrTon, E. 1870. Report on Geology of Montgomery County, Part III. Ohio Division of Geological Survey Report of Progress for 1869, 139-164.

Orton, E. 1871. The geology of Highland County. Ohio Geological Survey Report of Progress for 1870, 253-310.

Peterson, W.A. 1986. The geology of Kentucky - A text to accompany the geologic map. USGS Professional Paper 1151, online edition.

Pinsak, A.P. \& Shaver, R.H. 1964. The Silurian formations of northern Indiana. Indiana Geological Survey Bulletin 32, $1-87$.

RYDER, R.T. 2006. Stratigraphic framework and depositional sequences in the lower Silurian regional oil and gas accumulation, Appalachian Basin: from Licking County, Ohio, to
Fayette County, West Virginia. USGS Scientific Investigations Map 2916, 2 map sheets and explanatory pamphlet.

Schumacher, G.A., Angle, M.P., Mott, B.E. \& Aden, D.J. 2012. Geology of the Dayton region in outcrop and core - a workshop and field-trip for citizen, environmental investigators, geologists, and educators. Ohio Department of Natural Resources, Division of Geological Survey, Open File Report OFR2012-1, 1-58.

Shaver, R.H. et al. 1986. Compendium of Paleozoic rock-unit stratigraphy in Indiana - a revision. Indiana Department of Natural Resources and Geological Survey Bulletin 59, 1-203.

SLUCHER, E.R. 2004. Generalized column of the bedrock units in Ohio. Ohio Department of Natural Resources, Division of Geological Survey, 1 p.

Slucher, E.R., Swinford, E.M., Larsen, G.E., Schumacher, G.A., Shrake, D.K., Rice, C.K., Caudill, M.R. \& Rea, R.G. 2006. Bedrock Geologic Map of Ohio. Ohio Department of Natural Resources, Division of Geological Survey, Map BG-1 (Version 6), mapsheet with explanatory text. 